IZA DP No. 7324

Health and Labour Income of Wage Earners and Self-Employed Workers in Cameroon

Benjamin Fomba Kamga

Arline Kengne Kamga

Martine Audibert

March 2013 


\title{
Health and Labour Income of Wage Earners and Self-Employed Workers in Cameroon
}

\author{
Benjamin Fomba Kamga \\ University of Yaoundé II \\ and IZA \\ Arline Kengne Kamga \\ University of Yaoundé II \\ Martine Audibert \\ CERDI-CNRS, Auvergne University
}

\author{
Discussion Paper No. 7324 \\ March 2013
}

\author{
IZA \\ P.O. Box 7240 \\ 53072 Bonn \\ Germany \\ Phone: +49-228-3894-0 \\ Fax: +49-228-3894-180 \\ E-mail: iza@iza.org
}

\begin{abstract}
Any opinions expressed here are those of the author(s) and not those of IZA. Research published in this series may include views on policy, but the institute itself takes no institutional policy positions. The IZA research network is committed to the IZA Guiding Principles of Research Integrity.

The Institute for the Study of Labor (IZA) in Bonn is a local and virtual international research center and a place of communication between science, politics and business. IZA is an independent nonprofit organization supported by Deutsche Post Foundation. The center is associated with the University of Bonn and offers a stimulating research environment through its international network, workshops and conferences, data service, project support, research visits and doctoral program. IZA engages in (i) original and internationally competitive research in all fields of labor economics, (ii) development of policy concepts, and (iii) dissemination of research results and concepts to the interested public.
\end{abstract}

IZA Discussion Papers often represent preliminary work and are circulated to encourage discussion. Citation of such a paper should account for its provisional character. A revised version may be available directly from the author. 
IZA Discussion Paper No. 7324

March 2013

\section{ABSTRACT \\ Health and Labour Income of Wage Earners and Self-Employed Workers in Cameroon}

The objective of this paper is to assess the relationship between the health and the income from work of wage earners and self-employed workers in Cameroon. Health status is measured by a self-assessment of an individual's health; and income is measured by the monthly wage of the wage earners and monthly profits of the self-employed workers. This paper uses a simultaneous equation model to explore the relationship between health and income, allowing for the endogeneity of health, income, and selection into each employment status. The data used in this study is obtained from the 2007 Cameroon household consumption survey. Using OLS estimates, we find a positive and significant effect of health on labour incomes for self-employed workers. Using TSLS IV estimates, we find that health has a positive and significant effect on incomes for self-employed women, but not for men. We also undertake a reverse effect analysis from income to health, using the ordered probit estimation process. We find that, for men, the effect of income on health status is positive and significant for wage earners. For women, this effect is positive and significant for the selfemployed.

JEL Classification: I12, J21, J31

Keywords: health, labour income, wage earners, self-employed, Cameroon

Corresponding author:

Benjamin Fomba Kamga

Faculty of Economics and Management

University of Yaoundé II

Yaoundé 237

Cameroon

E-mail: fomba1@yahoo.fr 


\section{Introduction}

Disease affects economic outcomes through different channels (Weil 2008). The simplest channel, according to Weil is the effect of disease on the productivity of workers, thereby reducing their marginal productivity and the number of hours worked. Grossman (1972) substantiates this by indicating that when the health condition of an individual worsens, they will devote more time to getting health care and less time to work. Regarding productivity, Chirikos (1993) indicates that poor health conditions can affect the productivity of workers via the number of years spent on the labor market (by making retirement more attractive).

Regarding cost, high health costs can push workers to suffer bad health conditions, or to make others work more in order to increase income to finance health expenses. In addition, to improve or maintain their health condition individuals need to invest in their health. This requires financial resources and time, though some activities undertaken on the labour market could also have a direct negative impact on their health through the stress generated by work. Because of these issues, the exact direction of the influence of health on labour productivity and income has not been proved (Dwyer \& Mitchell 1999), even if most of the empirical studies find a positive influence of health on labour market participation and income (Leung \& Wong 2002).

On an empirical front, the correlation between health and income largely results from the selection process associated with considering individuals in good health relative to employment statuses and rejecting those with poor health (Reppeti et al 1989; Waldron, 1991). Physical disability can directly limit the capacities sought by employers and consequently reduce incapacitated employees’ productivity at work. Dumont (2000) shows that Madagascan people confronted with health issues have low productivity because they are penalized in terms of access to the labour market. These disabled people are generally inactive, and when they carry on an activity it is often in low-productivity sectors.

The correlation between health and income has been the subject of several studies. These studies differ in health measurement and methodological approaches. The most commonly used health measurements for studying the correlation between health and income are Height, Weight and BMI. Using Height as a proxy of health, Strauss \& Thomas (1998) show a strong and positive correlation between adult height and hourly wages in urban Brazil. In a recent 
study, correcting for the effects of wages on height from potential endogeneity, Gao \& Smyth report a large effect of height on wages in China. Schultz (2002), and Schultz \& Tansel (1997) also report a significant effect of height on wages in Brazil and Ghana. They show that an increase by a centimeter in height in Brazil and Ghana is associated with an $8-10 \%$ increase in wages for both men and women.

Using Weight as proxy for health, Averett \& Korenman (1996), and Cawley (2004) found a wage penalty for obesity in the range of $6-12 \%$. In contrast, Behrman \& Rosenzweig (2001) and Bhattacharya \& Bundorf (2005) report no effect of body weight on hourly wages. In a more recent study, Han et al (2009) found that the often-reported negative relationship between BMI and wages is larger in occupations requiring interpersonal skills (which presumably have more social interactions).

Some studies focus on Africa. On a macroeconomic scale, Mwabu \& Fosu (2007) find that the economic toll of malaria in Africa amounts to at least $10 \%$ of gross domestic product per year. Gallup \& Sachs (2001) corroborate these finding by indicating that per capita GDP of malaria-endemic countries in tropical Africa in the 1990s was 1/3 of per capita GDP of countries that had been free of malaria three decades earlier (in the 1960s). On the microeconomic front, using household data for 1994, Mwabu (2007) shows that malaria morbidity in Kenya is associated with a $15-16 \%$ reduction in wages, with a $10-12 \%$ decline in farm output during the long rains, and with a much higher reduction in household income. Kamgnia (2007) finds that in Cameroon, malaria accounts for nearly $75 \%$ of working days lost due to illness, and for about $40 \%$ of annual household expenditure on health.

Following the economic crisis that affected Cameroon in 1986, public authorities took measures to restrict government expenditure. The consequence of this policy on the health sector was deceleration of the reinforcement dynamics of the health systems, limitations on the training of health workers, and interruption of the recruitment of nurses, nursing aides, laboratory technicians, etc. Following the changes to the health system caused by this crisis, a large proportion of medical costs are now borne by patients. The fall in the supply of healthcare led to the development of a very expensive private sector. This new medical dynamic had an impact on health indicators in Cameroon. Mortality among men between 1998 and 2004 stagnated at 4.4 \%o. As for women, it increased from 3.5 \%o in 1998 to 3.9 \%o 
in 2004. The low level of healthcare for individuals could account for their low productivity and consequently their low labour market incomes. This poor health could be the cause of the high level of poverty in Cameroon, which was around 40\% between 2001 and 2007. The role of health in the fight against poverty is made explicit in the Millennium Development Goals (MDGs), three of the eight goals are directly connected, and two are indirectly connected, to health, and so justify the relevance of this study which has the objective of evaluating the relationship between health and labour market income.

In this paper, we contribute to literature in several ways:- a. Using a large cross-sectional household survey conducted in Cameroon in 2007 we use subjective health indicators to assess individuals' health on the Likert 4-level scale in order to analyze the interaction between health and labour market income. This is because, despite the richness of this survey, information on objective indicators of health such as height, weight and calorie consumption are not included, b. Self-reported measurement of health has been the subject of several studies in the relationship between health and labour market participation (Stern 1989; Kreider 1999; Cai 2010). However, very few studies have focused on the relationship between income and self-reported health, especially in least developed countries ${ }^{1}$. In this study, we attempt to fill this gap by examining a bi-directional causality between health and income. Because the effects may vary with the nature of the activity, comparisons are drawn between self-employed workers and wage earners, treating sectoral choice as endogenous. Finally, differences between men and women provide further evidence to support the interpretation of the patterns we observe.

The next section presents data sources and discusses measurement issues. Section 3 outlines the methodology. Section 4 gives a discussion of the descriptive analysis of the relationship between health, employment status and income. In section 5 we comment on the empirical results, and section 6 offers conclusions.

\section{Data sources and measurement issues}

The data used in this paper comes from the third national household survey carried out in 2007 by the Cameroon National Institute of Statistics (NIS). The information contained in this

\footnotetext{
${ }^{1}$ In developed countries, studies by Cai (2007) and Jäckle \& Himmler (2010) use subjective health as a measure of health status to analyze the effects of health on wages.
} 
survey is on the characteristics of households and their members (age, sex, location, education, marital status, health, participation in the labour market (sector, income, number of activities, hours worked, employment history, etc). This survey dealt with 11,391 households for 51,191 individuals.

The sample is restricted to working-age Cameroonian men and women, aged between 18 and 65 years old (inclusive). People aged over the upper age limit are eligible for old age pension and are assumed to behave differently as a result (Stern 1989; Bound et al 1999). We exclude people under 18 from the analysis because the age limit for child labour is 17 in Cameroon. In addition, anyone who was undertaking full-time studies are also excluded (1,455 individuals). Individuals who declared themselves to be working, but failed to give information on their income or valued it at zero, were omitted from the sample (868 individuals).

\section{Measurement of health status and labour market income}

The health of individuals has several dimensions. Consequently, the measurement of health is not easy. It is based on several indicators. This measurement can take several forms or approaches (Breslow 1989; Perronnin et al 2006). The first is objective and based on a medical examination which enables detection of physiological anomalies and assessment of general physical fitness. The second is functional and consists of determining the competence for social functioning - “one’s ability to eat, walk or bathe without assistance” (Breslow 1989; Gertler \& Gruber 2002). Self-completed questionnaires or observations are used in determining that competence. The third approach is entirely subjective, individuals questioned on their perception of their own health, have to determine their health status by using a graduated scale like Likert measures. The standard self-reported health indicator is used in this paper, with four levels on a scale from "poor” to "very good” health. This self-reported health status is used as the discrete observed counterpart of the latent health stock in the model. Despite the problems encountered in self-reported health measurement, such as error of measure and endogeneity, it is still the most popular measurement of health available. Tausman \& Rosen (1982), and Jäckle (2010) have even argued that this measure is close to “objective”. In addition, the dataset includes respondents' reports of specific health limitations; they were asked if they experienced disabilities in seeing, walking, hearing, speaking, or other disabilities. A short-term shock is taken into account in this dataset by a health problem during the last 14 days, malaria, diarrhea and respiratory infection. 
In terms of employment, our analysis is restricted to individuals who are in wage earning employment including paid family work, self-employed workers and unemployed. Income for wage earning employment and paid family work or apprenticeship is the total monthly income received from the employer and income from any secondary activities. Income for the selfemployed is the monthly profit from their activity.

\section{Methodology}

\section{a. Overview of health and labor market outcome}

The endogeneity of health described above could be estimated if we could measure health accurately. However, often an individual's health cannot be measured precisely, and in most survey data only self-reported health measures are available. Although there is a large literature showing that self-reported health is a good independent predicator of mortality and morbidity (Lundberg \& Manderbacka 1996), there remains a concern over the use of selfreported health measures in labour supply models. This is because self-reported health may introduce another source of endogeneity resulting from the possibility that people out of the labour force, or in the informal sector, report poor health to justify their non-participation or their poor working conditions, a justification hypothesis which has previously been reported in the literature (Stern 1989; Bound 1991; Dywer \& Mitchell 1999; Kreider 1999). The consequence of this justification is that when self-reported health is used in labour supply models, the health variable becomes endogenous and the effect of health on labour market participation can be overestimated.

Based on the above arguments, the self-reported health of workers should generally be more relevant than that reported by non-workers. Kreider (1999); using this hypothesis suggests that the "true" measure of the health status of non-workers could be constructed with information collected from workers. The objective of this paper is to evaluate the interaction between health status and income from the labour market. This income is observable only for individuals who work. The model will estimate health and income equations only for workers. This approach will raise a problem of selection bias.

\section{b. Selection bias}

The selection problem is due to the fact that the choice to work or not to work is not exogenous, and individuals do not have the same probability of taking either choice. Here, the participation equation is given as:- 
$I^{*}=Z \gamma+v$

where $Z$ is a matrix of exogenous variables, $\gamma$ is a parameter vector, and $v$ is a random component. $I^{*}$ is latent, instead we observe $I=0$ (in case of non participation), $I=1$ (in case where individual is self-employed), $I=2$ (in case where individual is paid employment). Employment status $j \in\{0,1,2,3\}$ will be chosen by individual $i$ if $U_{i j}>U_{i k}, k \neq j$ and $k \in\{0,1,2,3\}$. Finally, the labour income equation is of a standard Becker-Mincer type, Inc $=X_{1} \beta_{1}+\mu_{1}$ where Inc is the natural logarithm of labour income, $X_{1}$ is a matrix of exogenous variables, $\beta_{1}$ is a parameter vector, and $\mu_{1}$ is an error component, which is normally distributed with mean zero. The health equation is also given by $h=X_{2} \beta_{2}+\mu_{2}$ where $h$ is the measure of individuals' health, $X_{2}$ is a matrix of exogenous variables, $\beta_{2}$ is a parameter vector, and $\mu_{2}$ is an error component, which is normally distributed with mean zero. Labour income and health are observed if $j \neq 0$. Hence, expected observed labour income and health are given by:

$$
\begin{aligned}
& E_{j}\left(I n c_{i j} \mid I=j\right)=X_{1} \hat{\beta}_{1 j}+E\left(\mu_{1 j} \mid I=j\right) \\
& E_{j}\left(h_{i j} \mid I=j\right)=X_{2} \hat{\beta}_{2 j}+E\left(\mu_{2 j} \mid I=j\right)
\end{aligned}
$$

Define the covariance between the error term of the labour participation and the earning equation as $\sigma_{u_{1 j}}=\operatorname{cov}\left(u_{1 j}, v\right)$, and analogously between the error term of the participation and the health equation as $\sigma_{u_{2 j}}=\operatorname{cov}\left(u_{2 j}, v\right)$. Moreover, let $\operatorname{var}\left(u_{1 j}\right)=\sigma_{\mu_{1 j}}^{2}$ and $\operatorname{var}\left(u_{2 j}\right)=\sigma_{\mu_{2 j}}^{2}$. In order to estimate the selection model, the variance of the error term has to be standardized as $\quad \operatorname{var}(v)=1$. Following Maddala (1983), $\quad E_{j}\left(\mu_{1 j} \mid I=j\right)=\sigma_{\mu_{1 j}} \lambda_{j} \quad$ and $E_{j}\left(\mu_{2 j} \mid I=j\right)=\sigma_{\mu_{2 j}} \lambda_{j}$ where $\lambda_{j}=\phi\left[\Phi\left(P_{j}\right)\right] / P_{j} . \phi$ is the univariate standard normal density function, $\Phi$ is the univariate standard normal distribution function, and $P_{j}=\operatorname{Pr}(I=j)=\operatorname{Exp}\left(K^{\prime}{ }_{j} Z_{i j}\right) / \sum_{j=0}^{2} \operatorname{Exp}\left(K^{\prime}{ }_{j} Z_{i j}\right)$ is the probability of choosing an employment status $j$. It is worth noting that $\lambda$ 's is the inverse Mill's ratio in a standard two-stage Heckit model (Heckman 1979).

The conditional labour income and health in equations (2) and (3) can be rewritten as:-

$$
E_{j}\left(I n c_{i j} \mid I=j\right)=X_{1} \hat{\beta}_{1 j}+\lambda_{j} \sigma_{\mu_{1 j}}
$$




$$
E_{j}\left(h_{i j} \mid I=j\right)=X_{2} \hat{\beta}_{2 j}
$$

The theoretical and empirical analyses both showed that income from the labor market depends on the health of individuals, and the health of individuals depends on their income. This means that $h \in\left\{X_{1}\right\}$ and $\operatorname{Inc} \in\left\{X_{2}\right\}$.

\section{c. Endogeneity of health and labour income}

To explore the relationship between self-reported health and income from the labour market, this study employs a simultaneous equation model. The first equation describes the determination of health and is derived from equation (5),

$$
h_{i j}^{* *}=\gamma_{1 j} I n c_{i j}^{*}+X_{h i} \beta_{h j}+\varepsilon_{1 i j}
$$

Where $h_{i}^{* *}$ is latent true health of individual $i$, which depends on the labour income $\operatorname{Inc} c_{i}^{*}$, and a set of exogenous variables $X_{h}, \varepsilon_{1}$ is a disturbance term. Note that $\left\{X_{h}\right\} \not \subset\left\{X_{2}\right\}$ because Inc $\notin\left\{X_{h}\right\}$. The justification endogeneity has not been accounted for in equation (6) because this equation concerns the determination of true health, not self-reported health.

The labour income equation derived from equation (4) is specified as

$$
I n C_{i j}^{*}=\gamma_{2 j} h_{i j}^{* *}+X_{L i} \varphi_{L}+\varepsilon_{2 i j}
$$

Where labour income $I n c_{i}^{*}$ is determined by true health $h_{i}^{* *}$, and a set of exogenous variables $X_{L} ; \varepsilon_{2}$ is a disturbance term. Note that $\left\{X_{L}\right\} \not \subset\left\{X_{1}\right\}$ because $\lambda_{j} \sigma_{\mu_{1 j}} \in\left\{X_{L}\right\} . X_{L}$ and $X_{h}$ may have some variables in common.

Because true health is not observed, another equation is introduced to relate true health and observed self-reported health,

$$
h_{i j}^{*}=h_{i j}^{* *}+\alpha_{j} I n c_{i j}^{*}+\varepsilon_{3 i j}
$$

where $h_{i j}^{*}$ is the latent measure of self-reported health status, which depends on true health $h_{i j}^{* *}$ and the labour income $I n c_{i j}^{*}$. The dependence of self-reported health on labour income reflects the justification endogeneity of self-reported health, which is made explicit in equation (8). A positive $\alpha$ implies that as labour income increases, workers overstate their health.

Substituting equation (6) into equation (8) gives

$h_{i j}^{*}=\theta_{1 j} I n c_{i j}^{*}+X_{h i} \beta_{h j}+\varepsilon_{h i j}$

where $\theta_{1 j}=\alpha_{j}+\gamma_{1 j}$ and $\varepsilon_{h i j}=\varepsilon_{1 i j}+\varepsilon_{3 i j}$. In the model only $\theta_{1 j}$ can be identified. $\gamma_{1 j}$ and $\alpha_{j}$ cannot be separately estimated because there are no true health measures in the data. This 
means that the two types of simultaneous endogeneity (true endogeneity and justification endogeneity) cannot be separated, and only the overall simultaneity endogeneity can be empirically examined. However, the sign of $\theta_{1 j}$ does provide useful information in terms of which of the two types of simultaneity endogeneity dominates. For example, if $\theta_{1 j}$ is estimated to have a negative sign, $\gamma_{1 j}$ must be negative, given that the justification hypothesis predicts a positive sign for $\alpha_{j}$. This means that the true endogeneity must be negative and dominates the justification endogeneity. If $\theta_{1 j}$ is positive, there are two possible explanations: the true endogeneity has a positive effect (i.e. $\gamma_{1 j} \succ 0$ ), or the true endogeneity has a negative effect, but is dominated by the justification endogeneity. In other words, if justification endogeneity is present, we would expect the estimate of $\theta_{1 j}$ to be positive and significant.

It follows from equation (8) that $h_{i j}^{* *}=h_{i j}^{*}-\alpha_{j} I_{i j}^{*}-\varepsilon_{3 i j}$. Substituting this equation into equation (7) gives

$I n c_{i j}^{*}=\theta_{2 j} h_{i j}^{*}+X_{L i} \beta_{L j}+\varepsilon_{L i j}$

where $\theta_{2 j}=\frac{\gamma_{2 j}}{1+\alpha_{j} \gamma_{2 j}}, \quad \beta_{L j}=\frac{\varphi_{L j}}{1+\alpha_{j} \gamma_{2 j}}$ and $\varepsilon_{L j}=\frac{\varepsilon_{2 j}-\gamma_{2 j} \varepsilon_{3 j}}{1+\alpha_{j} \gamma_{2 j}}$. As a result, $\varepsilon_{h j}$ and $\varepsilon_{L j}$ are correlated. Ignoring the correlation would result in inefficient estimation coefficients.

The latent dependent variables underlying the model need to be linked to their observed discrete counterparts. For the health variable, we use four levels of self-reported status as recorded in the data. The corresponding observed values of endogenous variables are:

$h_{i}=\left\{\begin{array}{l}3(=\text { very good }) \text { if } m_{2}<h_{i}^{*}<m_{3}=+\infty \\ 2(=\text { good }) \text { if } m_{1}<h_{i}^{*}<m_{2} \\ 1 \text { (= fair }) \text { if } m_{0}<h_{i}^{*}<m_{1} \\ 0 \text { (= poor }) \text { if }-\infty=m_{-1}<h_{i}^{*}<m_{0}\end{array}\right.$

where $\left(m_{0}, m_{1}, m_{2}\right)$ unobserved cut-off points to be estimated, and labour income, are the natural logarithm of incomes from all sources.

Equations (9), (10) and (11) constitute a simultaneous equation system. The parameters to be estimated are the structural coefficients $\theta_{1 j}, \theta_{2 j}, \beta_{L j}$ and $\beta_{h j}$ in equations (9) and (10), the cut-off points $\left(m_{0}, m_{1}, m_{1}\right)$ in equation (11). 


\section{d. Estimation method}

The estimation method consists of two steps. In the first step, equation (1) has to be estimated using a multinomial probit model. The estimate obtained at the first stage $\left(\gamma_{j}\right)$ is used to construct $\lambda_{j}$ which are Mill ratios as defined above. The second step consists of estimating the income equation and health equation. The method used to estimate the simultaneous equation system is a two-stage method which is a partial information maximum likelihood method. Equations (9) and (10) can be rewritten in their reduced forms:

$$
\begin{gathered}
h_{i j}^{*}=\frac{1}{1-\theta_{1 j} \theta_{2 j}}\left(X_{h} \beta_{h j}+X_{L} \beta_{L j} \theta_{1 j}\right)+\frac{\varepsilon_{h j}+\theta_{1 j} \varepsilon_{L j}}{1-\theta_{1 j} \theta_{2 j}}=X \pi_{h j}+\varepsilon_{h i j}^{*} \\
I n c_{i j}^{*}=\frac{1}{1-\theta_{1 j} \theta_{2 j}}\left(X_{h} \beta_{h j} \theta_{2 j}+X_{L} \beta_{L j}\right)+\frac{\theta_{2 j} \varepsilon_{h j}+\varepsilon_{L j}}{1-\theta_{1 j} \theta_{2 j}}=X \pi_{L j}+\varepsilon_{L i j}^{*}
\end{gathered}
$$

where $\{X\}=\left\{X_{h}\right\} \cup\left\{X_{L}\right\}, \pi_{h j}$ and $\pi_{L j}$ are the reduced-form coefficients parameters, $\varepsilon_{h j}^{*}$ and $\varepsilon_{L j}^{*}$ are the error components in the reduced-form equations.

\section{Two-stage method}

In the first stage, equations (12) and (13) (combined with equations (10) and (11)) can be estimated using ordered probit and ordinary least square respectively. The consistent estimates of $\pi_{h j}$ and $\pi_{L j}$ denoted as $\hat{\pi}_{h j}$ and $\hat{\pi}_{L j}$ can be used to construct predicted probabilities of latent health and predicted values for labour income, giving

$$
\hat{h}_{i j}^{*}=X \hat{\pi}_{h j}
$$

$$
\hat{I n c} c_{i j}^{*}=X \hat{\pi}_{L j}
$$

The second stage is to replace $h_{i j}^{*}$ and $I n c_{i j}^{*}$ in equations (9) and (10) by $\hat{h}_{i j}^{*}$ and $\hat{I} n c_{i j}^{*}$, and estimate the ordered probit and OLS again. The standard errors of the second stage parameter estimates need to be adjusted to reflect the fact that $\hat{\pi}_{h j}$ and $\hat{\pi}_{L j}$ are estimated from the first stage.

\section{Descriptive analysis}

\subsection{Health and labour market outcome}

Table 1 presents health status relative to labour force status for males and females. This relationship can be checked through the chi square test, which is significant at $1 \%$ for both males and females. The sense of this relationship is not easy to perceive through these 
descriptive statistics. For men, there is a positive relationship between labour force participation and health status. That is, the better the health, the more likely an individual is to participate in the labour force. For women, the relationship is ambiguous. For example, among those women whose health is very good, $24.71 \%$ do not participate in the labour force while for those whose health is fair, only $22.36 \%$ do not participate in the labour force.

Table 1: Labour force status and self-reported health for men and women (\%)

\begin{tabular}{|c|c|c|c|c|c|}
\hline \multirow[t]{2}{*}{ Labour force status } & \multicolumn{4}{|c|}{ Health status } & \multirow[b]{2}{*}{ All } \\
\hline & Poor & Fair & Good & Very good & \\
\hline Females & \multicolumn{5}{|c|}{ Pearson chi2(6) $=46.2409 \operatorname{Pr}=0.000$} \\
\hline In labour force & $72.67(0.0213)$ & $77.64(0.0097)$ & $79.79(0.0077)$ & $75.29(0.0060)$ & $76.79(0.0042)$ \\
\hline Not in labour force & $27.33(0.0213)$ & $22.36(0.0097)$ & $20.21(0.0077)$ & $24.71(0.0060)$ & $23.21(0.0042)$ \\
\hline In Self employment & $60.82(0.0233)$ & $59.41(0.0114)$ & $58.95(0.0095)$ & $55.00(0.0069)$ & $57.10(0.0049)$ \\
\hline In paid employment & $11.85(0.0154)$ & $18.23(0.0089)$ & $20.24(0.0078)$ & $20.29(0.0056)$ & $19.69(0.0039)$ \\
\hline Observations & 439 & 1,865 & 2,687 & 5,204 & 10,195 \\
\hline Males & \multicolumn{5}{|c|}{ Pearson chi2 $(6)=134.6474 \operatorname{Pr}=0.000$} \\
\hline In labour force & $77.27(0.0248)$ & $90.97(0.0076)$ & $91.77(0.0057)$ & $94.18(0.0030)$ & $92.69(0.0026)$ \\
\hline Not in labour force & $22.73(0.0248)$ & $9.03(0.0076)$ & $8.23(0.0057)$ & $5.82(0.0030)$ & $7.31(0.0026)$ \\
\hline In self-employment & $51.05(0.0296)$ & $52.35(0.0133)$ & $54.49(0.0104)$ & $54.92(0.0064)$ & $54.34(0.0050)$ \\
\hline In paid employment & $26.22(0.0261)$ & $38.62(0.0130)$ & $37.29(0.0101)$ & 39.27 (0.0063) & 38.35 (0.0049) \\
\hline Observations & 286 & 1,406 & 2,285 & 6,000 & 9,977 \\
\hline
\end{tabular}

Notes: Values in parentheses are standard deviation.

Table 2 reports the relationship between the different disability measures, other diseases like malaria, diarrhea and respiratory infection, and self-reported health. The table reports total numbers of individuals with particular conditions and what proportion of these individuals responded in each way to the self-reported health question. For example, 38.81\% of the 67 hearing disabled said their health is very good. Many people who suffered from malaria, diarrhea and respiratory infection said their health is fair. These proportions are $45.58 \%$, $47.19 \%$ and $42.80 \%$ for malaria, diarrhea and respiratory infection respectively. In the other sense, not suffering from the above diseases lead people to say their health is very good. These proportions are 59.36\%, 56.49\% and 58.06\% for malaria, diarrhea and infection respiratory respectively. It is important to note that individuals, who suffer from malaria, have the highest proportion among those reporting poor health. But also, many individuals with disabilities do not self-report bad health. For example, $54.76 \%$ of the 42 speech disabled said 
their health is very good. Some of this could be due to individuals misinterpreting the disabled question.

Table 2: Relationship between self-reported health and others health among workers (\%)

\begin{tabular}{lcccccc}
\hline & & Total & Poor & Fair & Good & Very good \\
\hline Ill since 14 days & Yes & 4,619 & $10.63(0.0045)$ & $35.25(0.0070)$ & $30.18(0.0068)$ & $23.94(0.0063)$ \\
& No & 12,458 & $0.39(0.0006)$ & $8.82(0.0025)$ & $22.85(0.0038)$ & $67.93(0.0042)$ \\
\hline Visual & Yes & 289 & $6.23(0.0142)$ & $34.60(0.0280)$ & $31.49(0.0274)$ & $27.68(0.0264)$ \\
& No & 16,788 & $3.11(0.0013)$ & $15.65(0.0028)$ & $24.72(0.0033)$ & $56.52(0.0038)$ \\
\hline Speech & Yes & 42 & $9.52(0.0458)$ & $7.14(0.0402)$ & $28.57(0.0706)$ & $54.76(0.0777)$ \\
& No & 17,035 & $3.15(0.0013)$ & $15.99(0.0028)$ & $24.83(0.0033)$ & $56.04(0.0038)$ \\
\hline Hearing & Yes & 67 & $7.46(0.0323)$ & $26.87(0.0546)$ & $26.87(0.0546)$ & $38.81(0.0600)$ \\
& No & 17,010 & $3.15(0.0013)$ & $15.93(0.0028)$ & $24.83(0.0033)$ & $56.10(0.0038)$ \\
\hline Walking & Yes & 226 & $11.50(0.0213)$ & $23.01(0.0281)$ & $28.76(0.0302)$ & $36.73(0.0321)$ \\
& No & 16,851 & $3.05(0.0013)$ & $15.87(0.0028)$ & $24.78(0.0033)$ & $56.29(0.0038)$ \\
\hline Others & Yes & 21 & $23.81(0.0952)$ & $19.05(0.0878)$ & $23.81(0.0952)$ & $33.33(0.1054)$ \\
& No & 17,056 & $3.14(0.0013)$ & $15.97(0.0028)$ & $24.84(0.0033)$ & $56.06(0.0038)$ \\
\hline Malaria & Yes & 1,108 & $20.13(0.0121)$ & $45.58(0.0150)$ & $26.17(0.0132)$ & $8.12(0.0082)$ \\
& No & 15,969 & $1.99(0.0011)$ & $13.91(0.0027)$ & $24.74(0.0034)$ & $59.36(0.0039)$ \\
\hline Diarrhea diseases & Yes & 178 & $16.85(0.0281)$ & $47.19(0.0375)$ & $23.60(0.0319)$ & $12.36(0.0247)$ \\
& No & 16,899 & $3.02(0.0013)$ & $15.64(0.0028)$ & $24.85(0.0033)$ & $56.49(0.0038)$ \\
\hline Respiratory infection & Yes & 806 & $14.52(0.0124)$ & $42.80(0.0174)$ & $27.54(0.0157)$ & $15.14(0.0126)$ \\
& No & 16,271 & $2.60(0.0012)$ & $14.64(0.0028)$ & $24.70(0.0034)$ & $58.06(0.0039)$ \\
\hline Notes: Var & Ves & & & &
\end{tabular}

Notes: Values in parentheses are standard deviation.

We now consider the relationship between disability measurements and potential diseases (malaria, diarrhea and respiratory infection) and labor market participation, particularly employment status and income. The crudest measure of this is reported in the crosstabulations of Tables 3 and 4. Table 3 shows the proportion of jobless people and workers who suffer from a disease or a specific disability. The number of those who have been ill in the two weeks previous to the data collection is high for both men and women. Concerning other diseases, it appears that malaria is an illness which affects both workers and the jobless; this confirms the position of malaria as a cause of mortality and medical consultation in Cameroon (Kamgnia 2007). It is followed by respiratory diseases. As far as disabilities are concerned, it can be seen that visual and mobility disabilities are more frequent among workers and unemployed in Cameroon. Speech and hearing disabilities are more represented among unemployed men and women. This analysis highlights the negative effect of these disabilities on labour market participation, and the neutrality of diseases on the employment status of individuals. 
Table 3: Others health indicators and employment (\%)

\begin{tabular}{lcccccc}
\hline & \multicolumn{2}{c}{ Men } & \multicolumn{2}{c}{ Women } \\
\hline Health & Out LF & Self-employment & Wage Earner & Out LF & Self-employment & Wage Earner \\
\hline Ill since 14 days & 26.34 & 24.97 & 22.03 & 29.67 & 32.50 & 26.39 \\
\hline Visual & 3.70 & 1.66 & 1.57 & 2.03 & 1.77 & 1.79 \\
\hline Speech & 1.10 & 0.40 & 0.33 & 0.25 & 0.12 & 0.10 \\
\hline Hearing & 0.82 & 0.60 & 0.20 & 0.42 & 0.38 & 0.20 \\
\hline Mobility & 5.21 & 1.62 & 1.24 & 1.69 & 1.22 & 1.00 \\
\hline Malaria & 4.53 & 5.55 & 4.78 & 6.47 & 8.40 & 6.72 \\
\hline Diarrhea diseases & 1.51 & 1.29 & 0.91 & 0.89 & 1.04 & 0.60 \\
\hline Respiratory infection & 4.12 & 3.98 & 4.07 & 4.02 & 5.76 & 4.93 \\
\hline
\end{tabular}

Table 4 reports the mean income at different levels of self-reported health across gender and employment status. There are several findings worth noting. First, men have a higher mean income than women at every level of self-reported health and employment status. The importance of this disadvantage for women is emphasised when you consider that, on average, women with very good health earn less than men with poor health in different employment status. Second, the ranking of income does not follow the ranking of health (particularly for men). For self-employed men, labour income does not change with health status, while for wage earners labour income changes in the opposite direction to changes in health. For example, wage earner men with very good health earn approximately 23000 FCFA less than those with fair health.

Table 4: Health and income distribution (in thousands FCFA)

\begin{tabular}{|c|c|c|c|c|}
\hline \multirow[b]{2}{*}{ Health status } & \multicolumn{2}{|c|}{ Men } & \multicolumn{2}{|c|}{ Women } \\
\hline & Self-employment & Wage earners & Self-employment & Wage earners \\
\hline Poor & 63.6336 (78.6814) & 105.7233 (119.0418) & 42.9066 (53.8906) & 51.5492 (62.6309) \\
\hline Fair & 72.2359 (104.0469) & 112.7170 (284.9013) & 48.8147 (51.0369) & 67.4488 (99.5783) \\
\hline Good & 68.1274 (91.3692) & $106.1290(357.0447)$ & 48.5352 (56.5229) & 61.9157 (101.6211) \\
\hline \multirow[t]{2}{*}{ Very good } & 70.3207 (93.7826) & 89.7492 (123.4704) & 51.6126 (56.4169) & 55.6825 (91.1548) \\
\hline & \multicolumn{4}{|c|}{ Comparison (\%) } \\
\hline Very good / Good & $2.19(0.71)$ & $-16.38(-1.93)^{* *}$ & $3.08(1.74) * *$ & $-6.23(-1.26)$ \\
\hline Very good / Fair & $-1.91(-0.49)$ & $-22.98(-2.90)^{*}$ & $2.80(1.44)^{* * *}$ & $-11.77(-2.02)^{* *}$ \\
\hline Very good/ Poor & $6.69(0.84)$ & $-15.97(-1.10)$ & $8.71(2.42) *$ & $4.13(0.32)$ \\
\hline Good/ Fair & $-4.11(-0.92)$ & $-6.59(-0.36)$ & $-0.28(-0.13)$ & $-5.53(-0.80)$ \\
\hline Good/ Poor & $4.49(0.57)$ & $0.40(0.01)$ & $5.63(1.51) * * *$ & $10.37(0.72)$ \\
\hline Fair/ Poor & $8.60(0.95)$ & $6.99(0.21)$ & $5.91(1.68) * *$ & 15.90 (1.12) \\
\hline
\end{tabular}

Values in parentheses indicate standard errors and those in bracket are t-student. ${ }^{*}(* *)\{* * *\}$ significant at $1 \%$ (5\%) $\{10 \%\}$. 
For self-employed women, there is a positive relationship between labour income and health status. The better the health, the higher is the labour income. But for wage earner women, the relationship between wages and health status is not so clear-cut. While among those who reported poor or fair health, the wage appeared to increase with health; those who reported fair health had the highest wage, which seems to be at odd with expectations. But the simple tabulation did not control for other observed and unobserved factors which may also affect labour income.

\subsection{Variables used in each equation}

Table A1 provides definitions for the variables included in the models. The grouping of the variables also describes the model specifications, which can be summarized as follows. The variables included in the labour market participation, health and income equations are age, age squared, marital status, education (four dummies), non labour income, non labour income squared, locality (three dummies), local employment, local unemployment, and number of children in the household. Additional exogenous variables included in the selection equation, but excluded from the health and labour income equations, are the household variables - age, age squared, labour income, labour income squared, experience on the labour market, experience on the labour market squared, years of education, years of education squared, and employment status. Additional exogenous variables included in the labour income equation, but excluded from the labour market participation and health equations, are rhythm of activity (three dummies), sector of activity (four dummies), firm size (four dummies), and experience on the labour market. Additional exogenous variables included in the health equation, but excluded from the labour market participation and labour income equations, are specific health conditions (four dummies), and different disabilities (four dummies). These variables are used as an instrument for self-reported health status, following a suggestion by Bound et al (1999) that it is reasonable to treat self-reported particular diseases as exogenous. Bound et al (1999) argue that survey questions which are more specific and concrete should be less subjective, and therefore less susceptible to the justification of endogeneity problem.

By including different variables in the labour income and health equations, the exclusion restriction required to identify the simultaneous equation model is satisfied. But the question remains as to whether it is reasonable to assume that the identifying instruments (e.g. firm size) affect labour income but not health. The identifying instruments used in the health equation are variables on specific diseases and different disabilities, which may not be the 
subject of questions. This is because if one believes Grossman's (1972) theory on health capital any occurrence of specific diseases or disabilities represents an adverse shock to underlying health capital. In addition, in the literature on the effect of health on labour force participation, it is a popular strategy to use long term health condition and specific diseases to instrument potentially endogenous self-reported health (e.g. Stern 1989; Bound 1991; Bound et al 1999; Disney et al 2006).

However, one may doubt whether the identifying instruments employed by the labour income equation, such as industry, firm size, labour market experience, and rhythm of activity, should be excluded from the health equation, although there are good reasons for them to be included in the labour income equation. For example, it can be argued that rhythm of activity should directly affect health because temporary or seasonal workers work shorter hours and the employment is not stable, but Haveman et al (1994) find that rhythm of activity has no direct effect on health. Despite these arguments, we conduct and report sensitivity analyses in the next section.

\subsection{Selected Descriptive Statistics}

Table 5 provides means and proportions of the selected variables used in the empirical model with a distinction between men and women, and their status in the labour market. The sample means and proportions are presented for these six groups. Among those who work there are 54.15\% men and 45.85\% women. Self-employed men and women are older, more experienced, more represented in the people with primary education, have been previously self-employed, work more in the informal sector, are more likely to work seasonally, supply less hours of work per week, live in rural areas, work more in the primary sector, work more in firms with less than two people, are usually head of household, more likely to get married, than those who are unemployed or wage earners.

Household labour incomes are higher in households of wage earners, and the level of education is lower in households where self-employed workers live. Non labour incomes are higher for men who are unemployed. These incomes can increase their wage reservation and reduce the probability of searching for a job. In addition wage earners, both men and women, are more represented among people with vocational training degrees. 
Table 5: Means/proportions for others variables

\begin{tabular}{|c|c|c|c|c|c|c|}
\hline \multirow[t]{2}{*}{ Variables } & \multicolumn{3}{|c|}{ Men } & \multicolumn{3}{|c|}{ Women } \\
\hline & Out LF & Self-employment & Wage earners & Out LF & Self-employment & Wage earners \\
\hline \multicolumn{7}{|l|}{ Characteristics } \\
\hline Age (Years) & 34.78 & 37.28 & 33.05 & 31.24 & 37.74 & 31.66 \\
\hline Head (\%) & 37.17 & 83.86 & 68.43 & 9.59 & 31.92 & 21.56 \\
\hline Single (\%) & 64.06 & 26.71 & 44.77 & 23.84 & 13.45 & 40.24 \\
\hline nbenf0_5 & .816 & 1.00 & .812 & 1.21 & 1.06 & 1.00 \\
\hline nbenf6_14 & 1.40 & 1.23 & 1.28 & 1.39 & 1.52 & 1.40 \\
\hline nbenf15_17 & 0.54 & 0.34 & 0.41 & 0.45 & 0.43 & 0.45 \\
\hline \multicolumn{7}{|l|}{ Household variables } \\
\hline Age mean (years) & 27.16 & 23.91 & 23.64 & 22.47 & 24.06 & 23.58 \\
\hline Age mean squared & 816.34 & 670.34 & 624.82 & 576.08 & 693.17 & 623.55 \\
\hline Mean labour income (FCFA) & 17060.22 & 30877.63 & 43508.37 & 20067.21 & 24854.35 & 35322.74 \\
\hline Labour income squared & $9.47 \mathrm{e}+08$ & $2.73 e+09$ & $6.79 e+09$ & $1.43 \mathrm{e}+09$ & $1.57 \mathrm{e}+09$ & $4.65 \mathrm{e}+09$ \\
\hline Mean of experience & 2.55 & 5.876 & 3.72 & 2.28 & 6.11 & 4.97 \\
\hline Mean of experience squared & 16.80 & 73.38 & 30.94 & 12.66 & 81.76 & 52.74 \\
\hline Education (years) & 7.418 & 4.888 & 7.14 & 5.48 & 4.74 & 6.68 \\
\hline Education squared (years) & 3124.569 & 946.19 & 1851.45 & 1817.175 & 1210.219 & 2028.35 \\
\hline Log employment & 0.80 & 1.04 & 1.09 & .758 & 1.09 & 1.17 \\
\hline \multicolumn{7}{|l|}{ Location } \\
\hline Yaoundé \& Douala & 36.35 & 13.41 & 29.04 & 30.98 & 13.38 & 25.60 \\
\hline Others town & 44.17 & 33.35 & 43.34 & 49.24 & 35.35 & 35.91 \\
\hline Rural forest & 19.48 & 53.25 & 27.63 & 19.78 & 51.26 & 38.50 \\
\hline \multicolumn{7}{|l|}{ Education (\%) } \\
\hline No education & 14.99 & 22.73 & 6.69 & 29.25 & 31.01 & 14.50 \\
\hline Primary & 28.89 & 40.82 & 28.78 & 26.84 & 41.79 & 26.81 \\
\hline Secondary $1^{\text {st }}$ & 24.90 & 21.61 & 24.76 & 27.35 & 19.91 & 26.46 \\
\hline Secondary $2^{\text {nd }} \&+$ & 31.22 & 14.84 & 39.76 & 16.55 & 7.29 & 32.14 \\
\hline Vocational training & 48.49 & 48.20 & 69.91 & 29.38 & 31.89 & 52.29 \\
\hline \multicolumn{7}{|l|}{ Job history (\%) } \\
\hline Self employed & 11.80 & 70.12 & 10.93 & 13.48 & 68.72 & 10.96 \\
\hline Wage earner & 18.11 & 7.12 & 45.35 & 4.02 & 1.84 & 23.46 \\
\hline Apprentice & 31.41 & 13.39 & 20.70 & 41.76 & 23.14 & 39.29 \\
\hline Student & 38.68 & 9.37 & 23.03 & 40.74 & 6.30 & 26.29 \\
\hline Informal (\%) & & 98.21 & 48.46 & & 99.35 & 65.69 \\
\hline hours per week & & 47.40 & 50.60 & & 39.74 & 41.49 \\
\hline Tenure & & 11.82 & 6.71 & & 11.66 & 7.52 \\
\hline NL income & 113.25 & 30.64 & 27.59 & 20.86 & 13.33 & 25.21 \\
\hline NL income squared & 180424.4 & 217097.3 & 77202.74 & 24494.52 & 14696.06 & 467572.8 \\
\hline \multicolumn{7}{|l|}{ Frequency of activity (\%) } \\
\hline Regular & & 64.40 & 70.94 & & 66.03 & 58.23 \\
\hline Seasonal & & 29.18 & 7.74 & & 26.49 & 19.44 \\
\hline Temporary & & 6.42 & 21.33 & & 7.47 & 22.33 \\
\hline \multicolumn{7}{|l|}{ Sector of activity (\%) } \\
\hline Primary & & 47.76 & 12.29 & & 49.49 & 34.13 \\
\hline Industry & & 12.21 & 20.00 & & 14.95 & 9.92 \\
\hline Trade & & 18.59 & 7.95 & & 21.47 & 6.88 \\
\hline Services & & 21.44 & 59.66 & & 0.02 & 49.08 \\
\hline \multicolumn{7}{|l|}{ Firm size (\%) } \\
\hline 1 employee & & 50.30 & 3.40 & & 52.05 & 5.53 \\
\hline$[2,5]$ employees & & 40.04 & 38.19 & & 41.95 & 49.20 \\
\hline$[6,20]$ employees & & 9.17 & 32.78 & & 5.79 & 30.13 \\
\hline 21 employees \& more & & 0.50 & 25.64 & & 0.21 & 15.14 \\
\hline
\end{tabular}




\section{Econometric Results}

\section{Importance of selection issues}

We will now start our discussion of the determinants of labour market participation (Table 6). For identification purposes, we chose average household information on labour income, labour income squared, experience, experience on the labour market squared, education, education squared, and employment, as the exclusion restrictions used in the labour participation equation, but not the health or labour income equations.

To check their validity as identifying instruments, we used an appropriate test. Useful summary statistics for assessing the potential biases in the second step are the first-step chi 2statistics for the significance of the identifying instruments. These are reported at the bottom of Table 6. In all cases the chi 2-statistics of the joint significance of the average household information are high, and these variables are jointly different from zero at $0 \%$ level of significance for men and women, thereby justifying the choice of exclusion variables. The validity of the instruments is confirmed using the Hausman test. The estimation of the labour force participation model is made both with and without instruments. The results of this test presented at the bottom of Table 6 show that the unrestricted model is the best at the $1 \%$ level for both men and women.

Examining the labour force participation equation (1) first, a significant impact of health on labour force participation is estimated. The positive sign of each level of self-reported health indicates that, others things being equal, better health increase the probability of labour force participation for both men and women, and for self-employment and wage earners.

To improve the explanatory power of the labour force participation equation, a number of socio-economic variables are added into the model. In particular individual age, individual age squared, education, vocational training, number of children, locality, local employment, local unemployment, job history, and the status of household head. Compared to household head, any other status in the household reduces the likelihood of participation in the labour market. The effects of age on participation in the labour market are nonlinear. The probability of participating in the labor market increases with age, but at a decreasing rate. For women, the likelihood of participation in the labor market as wage earners increases up to 40 years, and as self-employed increases up to 50 years. For men, these ages are respectively 18 years and 31 years. Education increases the probability of being employed for men as well as for women. But for men with more than the first level of secondary education, the likelihood of 
being self-employed declines. Vocational training seems to be an important factor in being in the labour market as self-employed or as a wage earner for both men and women.

Table 6: Results of selection into labour market status

\begin{tabular}{|c|c|c|c|c|}
\hline & \multicolumn{2}{|c|}{ Men } & \multicolumn{2}{|c|}{ Women } \\
\hline & Self -employed & Wage earner & Self -employed & Wage earner \\
\hline Age & $0.062(1.85) * * *$ & $0.123(3.68) *$ & $0.199(8.33) *$ & $0.237(8.50) *$ \\
\hline Age squared & $-0.002(-4.34)$ & $-0.0025(-6.47) *$ & $-0.002(-8.48) *$ & $-0.003(-8.67) *$ \\
\hline \multicolumn{5}{|l|}{ Education } \\
\hline Primary & $0.231(1.24)$ & $0.607(3.16) *$ & $0.397(3.32) *$ & $0.272(1.94) * * *$ \\
\hline Secondary 1st & $0.493(2.37) * *$ & $0.858(4.05) *$ & $0.370(2.57) *$ & $0.324(1.97)^{* *}$ \\
\hline Secondary $2^{\text {nd }} \&+$ & $0.113(0.51)$ & $1.022(4.58) *$ & $0.393(2.19) * *$ & $0.970(4.99) *$ \\
\hline Vocational training & $0.233(1.99) * *$ & $0.720(6.23) *$ & $0.635(7.33) *$ & $0.858(9.07) *$ \\
\hline \multicolumn{5}{|l|}{ Health } \\
\hline Fair health & $1.236(4.79) *$ & $1.498(5.76) *$ & $0.617(3.15) *$ & $0.757(3.16) *$ \\
\hline Good health & $1.406(5.63) *$ & $1.605(6.37) *$ & $0.801(4.18) *$ & $0.986(4.22) *$ \\
\hline Very good health & $1.620(6.79) *$ & $1.927(7.98) *$ & $0.704(3.80)$ & $0.870(3.83) *$ \\
\hline NL income & $-0.002(-5.32) *$ & $-0.003(-6.09) *$ & $-0.002(-2.25) * *$ & $-0.003(-3.32) *$ \\
\hline NL income 2 & $7.21 \mathrm{e}-07(4.11) *$ & $7.26 \mathrm{e}-07(4.15) *$ & $5.05 \mathrm{e}-07(0.78)$ & 7.25e-07 (1.12) \\
\hline \multicolumn{5}{|l|}{ Job history 2001} \\
\hline Self employed & $2.509(11.25) *$ & $0.572(2.53) *$ & $3.084(22.42) *$ & $0.418(2.57) *$ \\
\hline Salaried & $0.243(1.10)$ & $1.671(7.80) *$ & $0.973(4.59) *$ & $2.528(12.67) *$ \\
\hline Training/ search & $0.412(2.58) *$ & $0.286(1.84) * * *$ & $1.280(11.35) *$ & $0.889(7.40) *$ \\
\hline \multicolumn{5}{|l|}{ Regional variables } \\
\hline Log employed & $0.288(1.43)$ & $0.223(1.11)$ & $0.879(6.22) *$ & $1.198(7.71) *$ \\
\hline Log unemployment & $-0.316(-2.47) * *$ & $-0.170(-1.33)$ & $-0.774(-8.95) *$ & $-0.893(-9.41) *$ \\
\hline \multicolumn{5}{|l|}{ Locality } \\
\hline Urban area & $0.137(0.71)$ & $0.156(0.82)$ & $0.248(1.85) * * *$ & $0.197(1.33)$ \\
\hline Rural & $0.589(2.06) * *$ & $0.527(1.85) * * *$ & $0.610(3.11) *$ & $1.103(5.07) *$ \\
\hline \multicolumn{5}{|l|}{ Number of children } \\
\hline $0-5$ years & $-0.403(-5.96) *$ & $-0.446(-6.53) *$ & $-0.445(-8.96) *$ & $-0.392(-7.19) *$ \\
\hline $6-14$ years & $-0.118(-2.75) *$ & $-0.114(-2.68) *$ & $-0.155(-4.74) *$ & $-0.082(-2.30) * *$ \\
\hline $15-17$ years & $-0.089(-1.13)$ & $-0.092(-1.20)$ & $-0.189(-3.16) *$ & $-0.170(-2.53) * *$ \\
\hline \multicolumn{5}{|l|}{ Household variables } \\
\hline Single & $-0.229(-1.12)$ & $-0.014(-0.07)$ & $-0.235(-2.02) * *$ & $0.532(4.36) *$ \\
\hline Head & $3.679(18.31) *$ & $3.046(15.40) *$ & $3.065(20.79) *$ & $2.624(16.20) *$ \\
\hline Age mean & $-0.313(-7.93) *$ & $-0.305(-7.70) *$ & $-0.312(-12.75) *$ & $-.0287(-10.19) *$ \\
\hline Age mean squared & $0.004(7.12) *$ & $0.004(6.66) *$ & $0.004(11.95) *$ & $0.004(9.32) *$ \\
\hline mean of labour income & $0.00001(5.05) *$ & $0.00001(5.97) *$ & 7.54e-08 (0.04) & $-1.11 \mathrm{e}-07(-0.06)$ \\
\hline Mean labour income squared & $-9.32 \mathrm{e}-12(-3.23) *$ & $-9.76 \mathrm{e}-12(-3.78) *$ & $-1.47 e-12(-0.47)$ & $-2.81 \mathrm{e}-13(-0.10)$ \\
\hline Mean of Experience & $0.185(5.53) *$ & $0.128((3.83) *$ & $0.182(7.21) *$ & $0.246(9.16) *$ \\
\hline Mean of Experience squared & $-0.0018(-1.04)$ & $-0.0004(-0.22)$ & $-0.002(-1.50)$ & $-0.003(-2.15) * *$ \\
\hline Mean of Education (years) & $-0.021(-1.02)$ & $-0.024(-1.14)$ & $0.071(3.42) *$ & $0.139(6.16) *$ \\
\hline Mean of Education squared & $-0.00005(-3.13) *$ & $-0.00003(-2.24) * *$ & $-0.0001(-6.60) *$ & $-0.0001(-6.92) *$ \\
\hline Log employment & $3.828(18.73) *$ & $4.0867(20.22) *$ & $5.813(34.99) *$ & $6.075(32.95) *$ \\
\hline Constant & $-2.079(-1.62) * * *$ & $-4.0295(-3.15) *$ & $-9.240(-10.66) *$ & $-13.382(-13.66) *$ \\
\hline Observations & \multicolumn{2}{|c|}{9977} & \multicolumn{2}{|c|}{10195} \\
\hline Log likelihood & \multicolumn{2}{|c|}{-5379.889} & \multicolumn{2}{|c|}{-5470.259} \\
\hline Pseudo R2 & \multicolumn{2}{|c|}{0.393} & \multicolumn{2}{|c|}{0.450} \\
\hline $\begin{array}{l}\text { Wald tests on the joint significance of } \\
\text { household variables }\end{array}$ & \multicolumn{2}{|c|}{ Chi 2(16) $=745.65 *$} & \multicolumn{2}{|c|}{ Chi 2(16) $=1653.20 *$} \\
\hline Hausman test of validity of instruments & \multicolumn{2}{|c|}{ LR chi2 $(16)=1187.79 *$} & \multicolumn{2}{|c|}{ LR chi2 $(16)=3048.02 *$} \\
\hline
\end{tabular}

Note: $1 . t$-statistics in parentheses.

2. * ** and *** represent statistical significance at the $1 \%, 5 \%$ and $10 \%$ respectively.

The location analysis shows that individuals resident in the two biggest cities of Cameroon (Yaoundé and Douala) are more likely to be unemployed. This result confirms the fact that 
unemployment is higher in large cities and the high concentration of the rural workforce in agriculture and livestock. An increase in the number of unemployed in a locality decreases the probability of being employed. The number of children in the household is a barrier to participation in the labor market for both men and women.

\section{Importance of endogeneity issues}

Health reduced form equation estimates are equation (12) of Table A2. These are used to construct probabilities for each health status. Four health indicator variables (Ill since 14 days, malaria, diarrhea, and respiratory infection) and four long term health condition are included in the health equation only, and are used as an instrument for self-reported health status. The four health indicator variables are statistically significant at the1\% level for each employment status for men and women, but the four long term health condition are individually significant only for self-employed men. All the identifying instruments are jointly significant at a $1 \%$ level for men and for women for each employment status, thereby justifying the choice of exclusion variables. The validity of the instruments is confirmed using the Hausman test. The estimation of health equation is made both with and without instruments. The results of this test presented at the bottom of Table A2 show that the unrestricted model is the best at the $1 \%$ level for both men and women.

Labour income reduced form equation estimates are equation (13) of Table A3. These are used to construct predicted latent income variables. The firm characteristics size, sector of activities, tenure, vocational training, and rhythm of work, are included in the income equation only, and are used as an instrument for labour income. These are jointly significant for both men and women at the $1 \%$ level in different labour market status, and we can therefore conclude that the labour market income equation is well defined. In spite of these fairly large chis 2 statistics, a good deal of unexplained heterogeneity remains, as indicated by the low $\mathrm{R}^{2} \mathrm{~s}$, particularly for the labour income of self-employed women ${ }^{2}$.

\section{Structural self-reported health estimation}

The results of the structural form of the subjective health equation are presented in Table 7 and Table 8. Table 7 presents a simple ordered probit model of the health equation without

\footnotetext{
${ }^{2}$ Since we want to preserve the same estimate structure for the different equations, the structure of labour income equations for self-employed is preserved in this work, however result interpretation should bear this in mind.
} 
taking into consideration labour income endogeneity. Table 8 presents a two stage ordered probit model of the health equation, in which the income variable is the result from equation 13)2.

Table 7: Simple ordered probit structural subjective health equation

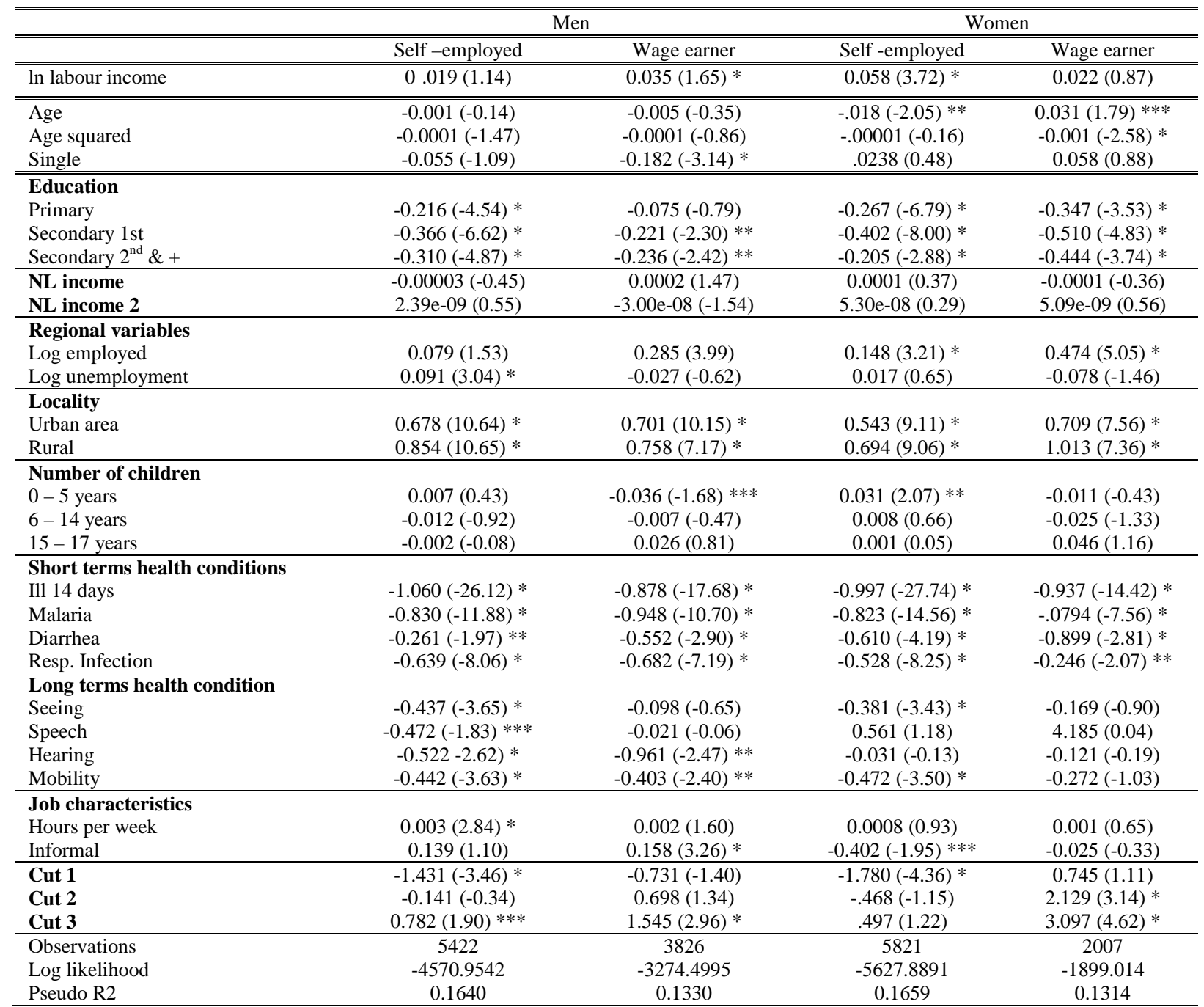

Note: 1. t-statistics in parentheses.

2. *, ** and $* * *$ represent statistical significance at the $1 \%, 5 \%$ and $10 \%$ respectively.

Income effects on health are positive and significant for men wage earners and women selfemployed when considered as exogenous. For self-employed men and wage earner women, income effects on health remain positive but non-significant. Thus, men earning a high salary and women with high labour income tend to report a very good health condition, while those with lower income tend to report poor health. The explanation for this result may be that income improves access to healthcare, healthcare quality, and willingness to go for treatment when one is sick; especially in Cameroon where health insurance covers a limited number of 
people. Taking into account the endogeneity of labor income in the estimation of the equation of health, we find that it is not significant and even displays a negative sign for self-employed men and wage earner women.

A recent illness (have been sick 14 days before the survey) decreases the likelihood of having a very good health condition for men and women in every employment status. A recent illness is followed or preceded by malaria for men and women in every employment status. Respiratory infection and diarrhea also decrease the likelihood of having a very good health condition. These results confirm the role of short-term conditions as predictors of health status.

The impacts of long-term specific health conditions or disabilities, particularly visual and mobility are large for self-employed men and women. Speech and hearing disabilities also have a negative impact on health status. But there are not disability effects on health for paid employment women. Disabled workers have less chance to get a job, but once employed the disability may no longer be regarded as a disease. This is why no disability among female wage-earners determines their health condition. In the same direction, visual and speaking disabilities do not predict health condition among wage earner men.

The relationship between health and education is ambiguous. Being more educated decreases the probability of reporting very good health. This result may be explained by the fact that educated people (like rich people) are more sensitive to their health. They can say that their health is fair, when a less educated person will say (for the same level of health) that his health is good. Similarly, it is possible that educated individuals are more inclined to take care of their health and to know their real health condition; this therefore reduces the probability of reporting very good health condition.

Wage earner women assess their health condition as improving with age up to 27 years old, while among self-employed women age affects their health negatively. This confirms the idea that older individuals report more health issues (Kenkel 1995). In general, living in the two biggest cities of Cameroon (Yaoundé \& Douala) influences health negatively. 
Occupation is a key indicator of socioeconomic status and it may serve to control for job quality in terms of health impact. Work in the informal sector has a positive influence on health assessment among male wage-earners, whereas this decreases with self-employed women. Job quality could also be measured in terms of number of hours worked per week. In this sense, working less could be caused by health problems particularly for self-employed men.

Table 8: Two stage ordered probit health equation

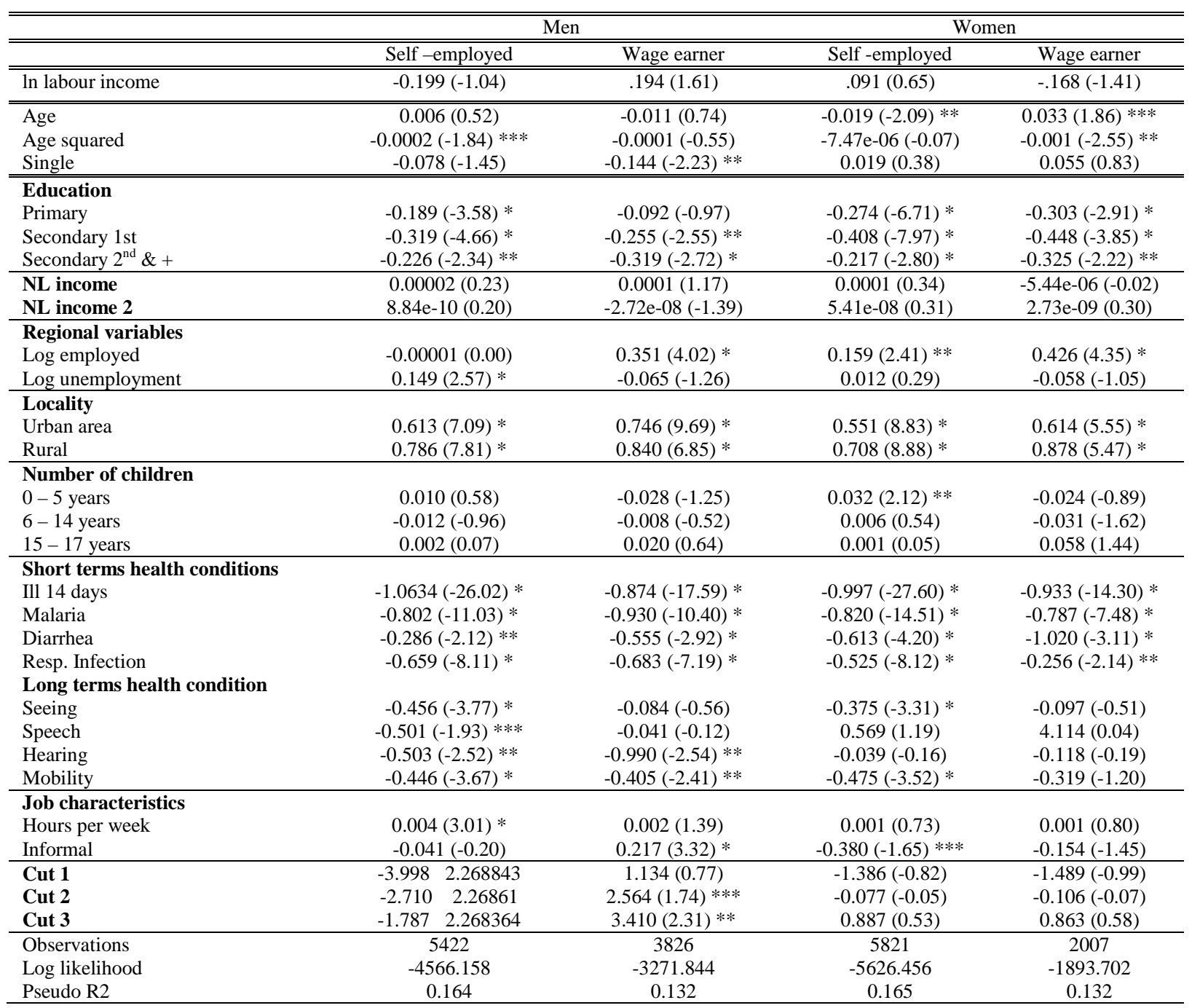

Note: 1. t-statistics in parentheses.

2. *,** and *** represent statistical significance at the $1 \%, 5 \%$ and $10 \%$ respectively.

\section{Structural labour income equation}

The analysis of the effect of health on income starts with the simple OLS regression of the logarithm of income where different categories of health status treated as exogenous variables appear as explanatory variables. The results are displayed in Table 9. Two potential problems may bias the estimation results when self-reported health is treated as an exogenous variable: 
measurement error and endogeneity. Nonetheless, these model results serve as a basis to be compared with models that tackle these biases.

Table 9: Structural OLS estimates for labour income

\begin{tabular}{|c|c|c|c|c|}
\hline & \multicolumn{2}{|c|}{ Men } & \multicolumn{2}{|c|}{ Women } \\
\hline & Self-employed & Wage earner & Self-employed & Wage earner \\
\hline \multicolumn{5}{|l|}{ " Subjective health } \\
\hline Fair health & $0.100(1.08)$ & $-0.259(-2.31) * *$ & $0.150(2.20) * *$ & $-0.016(-0.10)$ \\
\hline Good health & $0.117(1.32)$ & $-0.193(-1.76) * * *$ & $0.173(2.60) *$ & $0.108(0.71)$ \\
\hline Very good health & $0.145(1.70) * * *$ & $-0.218(-2.01) * *$ & $0.212(3.26) *$ & $0.084(0.56)$ \\
\hline Age & $0.019(2.09) *$ & "-0.004 (-0.34) & $0.008(0.97)$ & "-0.006 (-0.34) \\
\hline Age squared & $-0.0002(-2.49) * *$ & $0.0002(1.37)$ & $-0.0001(-0.92)$ & $0.00002(0.12)$ \\
\hline Single & $-0.052(-1.09)$ & $-0.174(-3.69) *$ & $0.094(2.06) * *$ & $-0.051(-0.74)$ \\
\hline Head & $0.194(3.23) *$ & $0.252(5.29) *$ & $0.015(0.44)$ & $0.115(1.68) * * *$ \\
\hline \multicolumn{5}{|l|}{ Education } \\
\hline Primary & $0.098(2.55) * *$ & $-0.089(-1.35)$ & $0.053(1.55)$ & $0.181(2.09) * *$ \\
\hline Secondary 1st & $0.193(4.19) *$ & $-0.028(-0.40)$ & $0.053(1.18)$ & $0.262(2.65) *$ \\
\hline Secondary $2^{\text {nd }} \&+$ & $0.309(5.30) *$ & $0.111(1.48)$ & $0.218(3.38) *$ & $0.577(4.95) *$ \\
\hline Vocational training & $0.033(1.02)$ & $-0.026(-0.67)$ & $0.078(2.53) * *$ & $0.195(3.39) *$ \\
\hline NL income & $0.0002(3.73) *$ & $0.0004(3.70) *$ & $0.0003(2.05) * *$ & $0.0004(2.11) * *$ \\
\hline NL income 2 & $-5.75 \mathrm{e}-09(-2.08) * *$ & $-2.30 \mathrm{e}-08(-1.51)$ & $-8.44 \mathrm{e}-08(-1.90) * * *$ & $-1.41 \mathrm{e}-08(-2.08) * *$ \\
\hline \multicolumn{5}{|l|}{ Job history 2001} \\
\hline Self employed & $0.461(4.24) *$ & $1.056(10.78) *$ & $0.038(0.41)$ & $0.167(1.36)$ \\
\hline Salaried & $-0.058(-0.60)$ & $-0.368(-5.24) *$ & $0.142(1.21)$ & $0.317(2.90) *$ \\
\hline Training/ search & $0.104(1.63)$ & $0.089(1.84) * * *$ & $-0.043(-0.62)$ & $-0.034(-0.45)$ \\
\hline \multicolumn{5}{|l|}{ Regional variables } \\
\hline Log employed & $-0.346(-8.04) *$ & $-0.397(-7.71) *$ & $-0.377(-9.33) *$ & $-0.255(-2.98) *$ \\
\hline Log unemployment & $0.244(9.76) *$ & $0.185(5.86) *$ & $0.262(10.97) *$ & $0.109(2.25) * *$ \\
\hline \multicolumn{5}{|l|}{ Locality } \\
\hline Urban area & $-0.304(-5.70) *$ & $-0.277(-2.49) *$ & $-0.188(-3.60) *$ & $-0.545(-6.47) *$ \\
\hline Rural & $-0.306(-4.40) *$ & $-0.450(-5.77) *$ & $-0.273(-4.05) *$ & $-0.808(-6.38) *$ \\
\hline \multicolumn{5}{|l|}{ Number of children } \\
\hline $0-5$ years & $0.004(0.33)$ & $-0.037(-2.32) * *$ & $-0.002(-0.14)$ & $-0.051(-2.31) * *$ \\
\hline $6-14$ years & $-0.011(-0.97)$ & $-0.012(-1.03)$ & $0.008(0.77)$ & $-0.024(-1.39)$ \\
\hline $15-17$ years & $0.021(0.92)$ & $0.038(1.64)$ & $-0.008(-0.38)$ & $0.041(1.17)$ \\
\hline \multicolumn{5}{|l|}{ Job characteristics } \\
\hline Hours per week & $0.003(3.69) *$ & $0.0002(0.26)$ & $0.004(4.52) *$ & $0.002(1.52)$ \\
\hline Experience & $0.004(2.15) * *$ & $0.006(2.64) *$ & $-0.0003(-0.17)$ & $0.011(2.73) *$ \\
\hline Informal & $-0.702(-6.47) *$ & $-0.251(-6.04) *$ & $-0.676(-4.08) *$ & $-0.411(-5.12) *$ \\
\hline \multicolumn{5}{|l|}{ Activity characteristics } \\
\hline Seasonal & $-0.067(-1.87) * * *$ & $-0.057(-0.95)$ & $-0.049(-1.49)$ & $-0.344(-4.33) *$ \\
\hline Temporary & $-0.073(-1.24)$ & $-0.120(-3.09) *$ & 0.077 (1.45) & $-0.025(-0.40)$ \\
\hline \multicolumn{5}{|l|}{ Sector of activity } \\
\hline Industry & $-0.001(-0.03)$ & $0.063(1.07)$ & $-0.207(-4.41) *$ & $-0.369(-3.41) *$ \\
\hline Trade & $0.048(0.94)$ & $-0.042(-0.58)$ & $-0.180(-3.95) *$ & $-0.379(-3.11) *$ \\
\hline Services & $-0.010(-0.19)$ & 0.075 (1.33) & $-0.179(-3.55) *$ & $-0.249(-2.68) *$ \\
\hline \multicolumn{5}{|l|}{ Firm size } \\
\hline $2-5$ employees & $0.077(2.25) * *$ & $0.021(0.25)$ & $0.072(2.34) * *$ & $0.184(1.66) * * *$ \\
\hline 6 - 20 employees & $0.183(3.24) *$ & $0.080(0.93)$ & $0.134(2.17) * *$ & $0.294(2.48) * *$ \\
\hline At least 21 employees & $0.474(2.34) * *$ & $0.171(1.88) * * *$ & $0.393(1.36)$ & $0.297(2.22) * *$ \\
\hline Selection term & $1.678(3.69) *$ & $-4.666(-12.64) *$ & $-0.238(-0.89)$ & $-0.150(-0.39)$ \\
\hline Constant & $10.710(27.25) *$ & $14.974(32.66) *$ & 11.9959 (33.95) * & $11.809(17.35) *$ \\
\hline Observations & 5422 & 3826 & 5821 & 2007 \\
\hline Adjusted $\mathrm{R}^{2}$ & 0.103 & 0.320 & 0.050 & 0.313 \\
\hline
\end{tabular}

Note: $1 . t$-statistics in parentheses.

2. * ${ }^{* *}$ and ${ }^{* * *}$ represent statistical significance at the $1 \%, 5 \%$ and $10 \%$ respectively.

The results of the different specifications are significant as a whole, but with very low $\mathrm{R}^{2}$ for self-employed men and self-employed women, this may highlight an unobserved heterogeneous problem. Analysis of the results should be carried out while keeping this problem in mind. For men, the selection term is significant and positive for self-employed, but negative for wage earner. A positive coefficient would imply a positive selection, which 
means average earnings for the observed (sorted) self-employed men would be greater than we would observe for a random sorting. This confirms the Maloney (2004) results which indicated that self-employment is a voluntary choice. A negative coefficient would imply a negative selection, meaning that the average wage for the observed (sorted) wage earner men would be lower than we would observe for a random sorting. For women, none of the selection variables is significant. Thus, in contrast to men, no evidence of non-random sorting of women workers across the different labour market statuses emerges.

These results show that self-employed men with very good health have higher labour income than people with poor, fair or good health. But self-employed men with fair or good health have statistically the same labour income as people with poor health. For self-employed women, labour income increases with level of self-reported health. Hence, compared to women with poor health, self-employed women with very good health, good health or fair health, earn a labour income $23.61 \%$; $18.89 \%$ or $16.18 \%$ higher. In contrast, for wage earner men labour income decreases with level of health status. Hence, compared to men with poor health, wage earner men with very good health, good health or fair health earn a labour income $19.59 \%$; 17.55 or $22.82 \%$ lower. These results corroborate the statistical comparison of labour income by health status. This situation may be due to the fact that sick workers are more inclined to work in order to earn more income, possibly to pay for their healthcare.

Taking into consideration subjective health endogeneity, it appears that income increases with health condition among self-employed women only. Thus, the fact that these women think they are in good health increases their income by $88.32 \%$. There are no health effects on wages for both men and women, and we found a negative effect of health on the labour income of self-employed men. These results are similar to those found in African countries, they show that diseases such as malaria affect the agricultural output of households, but not activity income such as salaries nor global home expenses (Mwabu 2007). For wage-earners, these results are due to the fact that their wages are generally paid monthly, and do not change when they are ill. Furthermore, they are more often in the public and formal sectors where salaries are determined beforehand, paid every month, and not reduced in case of sickness.

The estimates for all other variables are very similar between the simple OLS model and the two stages least squared model, and almost all the significant variables have the expected 
signs. Therefore, comments concerning these variables will refer to the TSLS estimates of Table 10. Wage earner men without partner are estimated to suffer a wage penalty of $15.12 \%$ compared with married men, while self-employed women without partner are estimated to have an income premium of about $10 \%$ compared with married women. According to the human capital theory (Becker 1964; Mincer 1974), the higher the education level, the higher the labour income. In the context of Cameroon, this is true only for self-employed men and wage earner women. For self-employed women and wage earner men, the returns of education begin to be positive and significant from second level of secondary education. Vocational training is rewarded for women only. For men and women, work experience is rewarded, but for self-employed men it is rewarded at a decreasing rate ${ }^{3}$. Looking at employment history as a quality of experience, results show that for men, being on selfemployment increase labour income both among those who remained self-employed and those who became employees. Self-employed men and self-employed women in the informal sector earn a labour income about 50\% lower than those in the formal sector. Working more for more income is true only for self-employed workers. Additional hours of work increase their labour income by about $0.35 \%$ for both men and women. For both self-employed men and women increasing local employment has a negative effect on labour income while increasing local unemployment has a positive effect on labour income. This means that when local employment increases, wages and profits from self-employment activities decrease due to competition.

Working outside the two biggest cities of Cameroon (Yaoundé and Douala), or in seasonal or temporary activities, reduces labour income. Self-employed men and wage earner women working in medium-sized firms (at least 21 employees) earn significantly more than in small firms (6 to 20 employees), who in turn earn more than self-employed men and wage earner women working in micro firms (less than 6 employees). The number of children (especially up to 5 years olds) is associated with lower labour income for wage earner men and women.

Women in the primary sector earn a labour income higher than those who are in the other sectors (industry, services or trade). For example, wage earner women in the industry sector earn a wage $29 \%$ lower than those in the primary sector. For both women and men, labour income increases as non labour income increases. For self-employment, non labour income

\footnotetext{
${ }^{3}$ This comes from the relationship between age and salary. For self-employed worker men, labour income increases up to 30 years old.
} 
can be used as capital, and for wage earners non labour income increases the reservation wage, and therefore the real wage.

Table 10: Two stages least squared structural estimates for labour income

\begin{tabular}{|c|c|c|c|c|}
\hline & \multicolumn{2}{|c|}{ Men } & \multicolumn{2}{|c|}{ Women } \\
\hline & Self-employed & Wage earner & Self-employed & Wage earner \\
\hline \multicolumn{5}{|c|}{ "Subjective health predicted } \\
\hline Fair health & $-1.895(-2.33) * *$ & $0.740(0.84)$ & $0.298(0.52)$ & $-2.5258(-1.41)$ \\
\hline Good health & $-0.052(-0.17)$ & $0.117(0.30)$ & $0.633(2.92) *$ & $0.077(0.10)$ \\
\hline Very good health & $-1.035(-2.03) * *$ & $0.511(0.85)$ & $0.190(0.52)$ & $-1.681(-1.33)$ \\
\hline Age & $0.018(1.90) * * *$ & -0.003(-0.23) & $0.005(0.64)$ & -0.004 (-0.25) \\
\hline Age squared & $-0.0003(-2.41) * *$ & $0.0001(1.29)$ & $-0.0001(-0.79)$ & $-0.00001(-0.08)$ \\
\hline Single & $-0.053(-1.12)$ & $-0.164(-3.43) *$ & $0.097(2.14) * *$ & $-0.043(-0.62)$ \\
\hline Head & $0.193(3.21) *$ & $0.245(5.13) *$ & $0.010(0.30)$ & $0.110(1.60)$ \\
\hline \multicolumn{5}{|l|}{ Education } \\
\hline Primary & $0.082(2.09) * *$ & $-0.079(-1.19)$ & 0.035 (1.02) & $0.121(1.35)$ \\
\hline Secondary 1st & $0.166(3.47) *$ & $-0.012(-0.18)$ & $0.026(0.57)$ & $0.170(1.66) * * *$ \\
\hline Secondary $2^{\text {nd }} \&+$ & $0.290(4.91) *$ & $0.134(1.76) * * *$ & $0.205(3.17) *$ & $0.498(4.12) *$ \\
\hline " Vocational training & 0.037 (1.13) & "-0.018 (-0.46) & ".0766 (2.48) ** & 0.195 (3.39) * \\
\hline NL income & $0.0003(3.75) *$ & $0.0004(3.51) *$ & $0.0004(2.16) * *$ & $0.0004(2.12) * *$ \\
\hline NL income 2 & $-5.70 \mathrm{e}-09(-2.07) * *$ & $-2.11 \mathrm{e}-08(-1.38)$ & $-8.30 \mathrm{e}-08(-1.87) * * *$ & $-1.36 \mathrm{e}-08(-2.01) * *$ \\
\hline \multicolumn{5}{|l|}{ Job history 2001} \\
\hline Self employed & $0.466(4.30) *$ & $1.025(10.57) *$ & $0.027(0.29)$ & $0.150(1.22)$ \\
\hline Salaried & $-0.045(-0.47)$ & $-0.342(-4.91) *$ & $0.138(1.18)$ & $0.321(2.94) *$ \\
\hline Training/ search & $0.109(1.71) * * *$ & $0.094(1.91) * * *$ & $-.055(-0.79)$ & $-0.018(-0.24)$ \\
\hline \multicolumn{5}{|l|}{ Regional variables } \\
\hline Log employed & $-0.341(-7.93) *$ & $-0.407(-7.74) *$ & $-0.364(-8.92) *$ & $-0.188(-2.09) * *$ \\
\hline Log unemployment & $0.252(9.91) *$ & $0.186(5.91) *$ & $0.265(11.08) *$ & $0.102(2.12) * *$ \\
\hline \multicolumn{5}{|l|}{ Locality } \\
\hline Urban area & $-0.254(-4.37) *$ & $-0.306(-5.24) *$ & $-0.151(-2.78) *$ & $-0.436(-4.56) *$ \\
\hline Rural & $-0.244(-3.22) *$ & $-0.482(-5.74) *$ & $-0.219(-3.10) *$ & $-0.637(-4.43) *$ \\
\hline \multicolumn{5}{|l|}{ Number of children } \\
\hline $0-5$ years & $0.005(0.40)$ & $-0.038(-2.36) * *$ & $0.002(0.17)$ & $-0.051(-2.32) * *$ \\
\hline $6-14$ years & $-0.012(-1.11)$ & $-0.010(-0.87)$ & $0.008(0.82)$ & $-0.030(-1.71) * * *$ \\
\hline $15-17$ years & $0.022(0.96)$ & $0.036(1.54)$ & $-0.008(-0.40)$ & $0.046(1.32)$ \\
\hline \multicolumn{5}{|l|}{ Job characteristics } \\
\hline Hours per week & $0.003(3.87) *$ & $0.0002(0.21)$ & $0.004(4.74) *$ & $0.002(1.66) * * *$ \\
\hline Experience & $0.004(2.15) * *$ & $0.006(2.60) *$ & $-0.0001(-0.09)$ & $0.012(2.92) *$ \\
\hline Informal & $-0.692(-6.37) *$ & $-0.257(-6.11) *$ & $-0.704(-4.24) *$ & $-0.421(-5.23) *$ \\
\hline \multicolumn{5}{|l|}{ Activity characteristics } \\
\hline Seasonal & $-0.063(-1.75) * * *$ & $-0.058(-0.97)$ & $-0.039(-1.15)$ & $-0.303(-3.75) *$ \\
\hline Temporary & $-0.070(-1.20)$ & $-0.121(-3.10) *$ & $0.076(1.43)$ & $-0.014(-0.22)$ \\
\hline \multicolumn{5}{|l|}{ Sector of activity } \\
\hline Industry & $-0.0001(-0.01)$ & $0.059(1.01)$ & $-0.202(-4.28) *$ & $-0.342(-3.18) *$ \\
\hline Trade & $0.048(0.93)$ & $-0.045(-0.61)$ & $-0.178(-3.92) *$ & $-0.353(-2.89) *$ \\
\hline Services & $-0.011(-0.22)$ & $0.070(1.24)$ & $-0.181(-3.59) *$ & $-0.212(-2.26) * *$ \\
\hline \multicolumn{5}{|l|}{ Firm size } \\
\hline $2-5$ employees & $0.074(2.16) * *$ & $0.018(0.22)$ & $0.073(2.37) * *$ & $0.173(1.56)$ \\
\hline 6 - 20 employees & $0.178(3.15) *$ & $0.080(0.93)$ & $0.138(2.24) * *$ & $0.273(2.29) * *$ \\
\hline At least 21 employees & $0.471(2.33) * *$ & $0.171(1.87) * * *$ & $0.393(1.36)$ & $0.276(2.06) * *$ \\
\hline Selection term & $1.657(3.65)^{*}$ & $-4.497(-12.44) *$ & $-0.256(-0.96)$ & $-0.149(-0.39)$ \\
\hline Constant & $11.678(19.82) *$ & $14.270(21.03) *$ & $11.850(25.68) *$ & $12.709(10.08) *$ \\
\hline Observations & 5426 & 3826 & 5821 & 2007 \\
\hline Adjusted R2 & 0.103 & 0.320 & 0.050 & 0.314 \\
\hline
\end{tabular}

Note: 1 . t-statistics in parentheses.

2. *** and ${ }^{* * *}$ represent statistical significance at the $1 \%, 5 \%$ and $10 \%$ respectively. 


\section{Conclusions}

This paper uses a cross-section data simultaneous equation model to examine the relationship between subjective health and labour income in Cameroon. OLS and two-stage methods are used to estimate the model. A distinction is made between 3 types of labour market participation - unemployment, self-employment and paid employment; labour incomes are analysed only for the two last types of participation. For self-employment, labour incomes are profit, for paid employment labour incomes are wages. Health status is measured by self reported health. Using the 2007 household consumption survey for Cameroon, we confirm the common finding in the literature that health has a positive and significant effect on incomes for both self-employed men and women when OLS are used. Using the TSLS method, health has a positive and significant effect on labour incomes for self-employed women only. The reverse effect from income to health was found to be different between the employment statuses. When probit without endogeneity is used, incomes affect health status positively and significantly for self-employed men, wage earner men, and self-employed women. Using IV regression, the effects of labour income on health remain positive and significant for wage earner men, while it becomes negative and significant for self-employed men. The negative reverse effect for self-employed men suggests that the commonly held view that rich men have a good health status might not be true, and that their incomes must be complement to health infrastructures.

The negative reverse effect of incomes on health for self-employed men implies that treating health as an exogenous variable could lead to an underestimation of the effect of health on labour income for men. Therefore, the significant effect of health on labour incomes found when treating health as an exogenous variable must be interpreted carefully. In summary, the simultaneous equation corrected from selection bias estimated in this paper provides more insights into the relationship between health and labour income than a single equation model could. 


\section{Appendices}

Table A1: Definitions of variables

\begin{tabular}{|c|c|}
\hline Variables & Definitions \\
\hline \multicolumn{2}{|l|}{ Panel A } \\
\hline Labour force status & 0 non-participation, 1self-employment, 2 wage earner \\
\hline Health (self-reported) & $0=$ poor, 1 = fair, 2 = good, 3 = very good \\
\hline Log Income & Natural logarithm of respondent's labour income per month \\
\hline \multicolumn{2}{|r|}{ (1) } \\
\hline Age & Age in years \\
\hline Age squared & Age squared \\
\hline Married & 1 if married at time of survey interview or in de facto \\
\hline Female & 1 if respondent is a woman \\
\hline Head of household & 1 if respondent is a head of a household \\
\hline NL income & Monthly income from investments, private transfers, any pension, etc. in FCFA \\
\hline NL income squared & Monthly income from investments, private transfers, any pension, etc. in FCFA squared \\
\hline Education & $\begin{array}{l}\text { Four dummies variables indicating the level of education; categories: no education, primary education, first } \\
\text { level of secondary education and second level of secondary education or more. }\end{array}$ \\
\hline Location & $\begin{array}{l}\text { Three dummies variables indicating the location of individuals; categories: Yaoundé or Douala, others towns } \\
\text { and rural. }\end{array}$ \\
\hline \multicolumn{2}{|r|}{ (1) } \\
\hline Log of employment & Natural logarithm of number of employment in the department \\
\hline Log of unemployment & Natural logarithm of unemployed in the department \\
\hline Job history & $\begin{array}{l}\text { Four dummies variables indicating the job position of each worker in 2001; categories: self-employed, wage } \\
\text { earner, apprentice or on job search and student. }\end{array}$ \\
\hline Structure of household & Number of person who age old is $[0,5],[6,14],[15,17]$ \\
\hline \multicolumn{2}{|l|}{ household information } \\
\hline Average age of household & Average age of the household \\
\hline Average age squared & Average age of the household squared \\
\hline Average years of education & Average years of education \\
\hline Average years of education & Average of education squared \\
\hline Average experience & Average experience on the labour market \\
\hline $\begin{array}{l}\text { average experience squared } \\
\text { Job information }\end{array}$ & Average experience on the labour market squared \\
\hline$\overline{\text { Hours per week }}$ & Number of hours worked per week \\
\hline Informal & 1 if respondent works in the informal sector \\
\hline Experience & Number of year in the labour market \\
\hline \multicolumn{2}{|l|}{ Health equation only } \\
\hline Diseases & $\begin{array}{l}\text { Four dummies variables indicating different diseases: have been sick since } 14 \text { days, malaria, diarrhea and } \\
\text { respiratory infection. }\end{array}$ \\
\hline Disability & Four dummies variables indicating different disabilities: seeing, speech, hearing and mobility \\
\hline $\begin{array}{l}\text { Income equation only } \\
\text { Tenure }\end{array}$ & $\begin{array}{l}\text { Four dummy variables indicating different firm sizes; categories: up to } 1 \text { employee; } 2-5 \text { employees; } 6-20 \\
\text { employees and larger than } 21 \text { employees. }\end{array}$ \\
\hline Size of enterprise & \\
\hline Sector of activity & Four dummy variables indicating different sectors (primary, industry, services and trade). \\
\hline
\end{tabular}


Table A2: Reduced form estimates for subjective health

\begin{tabular}{|c|c|c|c|c|}
\hline & \multicolumn{2}{|c|}{ Men } & \multicolumn{2}{|c|}{ Women } \\
\hline & Self -employed & Wage earner & Self -employed & Wage earner \\
\hline Age & "-0.005 (-0.44) & $0.002(0.15)$ & $-0.014(-1.46)$ & $0.030(1.54)$ \\
\hline Age squared & $-0.0001(-1.06)$ & $-0.0002(-1.40)$ & $-0.0001(-0.53)$ & $-0.0005(-2.27) * *$ \\
\hline Single & $-0.063(-1.09)$ & $-0.141(-2.18) * *$ & $0.030(0.58)$ & $0.062(0.88)$ \\
\hline Head & $-0.014(-0.22)$ & $0.104(1.60)$ & $-0.016(-0.45)$ & $-0.040(-0.53)$ \\
\hline \multicolumn{5}{|l|}{ Education } \\
\hline Primary & $-0.206(-4.21) *$ & $-0.083(-0.87)$ & $-0.246(-6.11) *$ & $-0.299(-2.85) *$ \\
\hline Secondary 1st & $-0.346(-5.99) *$ & $-0.245(-2.47) * *$ & $-0.393(-7.45) *$ & $-0.462(-3.96) *$ \\
\hline Secondary $2^{\text {nd }} \&+$ & $-0.278(-4.18) *$ & $-0.254(-2.51) * *$ & $-0.207(-2.76) *$ & $-0.406(-3.06) *$ \\
\hline Vocational training & $-0.015(-0.41)$ & $0.034(0.70)$ & $0.046(1.27)$ & $-0.027(-0.42)$ \\
\hline NL income & $-0.00002(-0.32)$ & $0.0002(1.62)$ & $0.0001(0.55)$ & $-0.00004(-0.22)$ \\
\hline NL income 2 & $2.01 \mathrm{e}-09(0.46)$ & $-3.26 \mathrm{e}-08(-1.67) * * *$ & $3.79 e-08(0.28)$ & $4.04 \mathrm{e}-09(0.45)$ \\
\hline \multicolumn{5}{|l|}{ Job history 2001} \\
\hline Self employed & $0.083(1.07)$ & $-0.043(-0.48)$ & $-0.086(-1.05)$ & $-0.126(-1.12)$ \\
\hline Salaried & $0.072(0.75)$ & $-0.116(-1.55)$ & $-0.044(-0.32)$ & $0.016(0.15)$ \\
\hline Training/ search & $0.039(0.51)$ & $-0.094(-1.37)$ & $-0.139(-1.75) * * *$ & \\
\hline \multicolumn{5}{|l|}{ Regional variables } \\
\hline Log employed & $0.062(1.18)$ & $0.268(3.75) *$ & $0.136(2.92) *$ & $0.481(5.04) *$ \\
\hline Log unemployment & $0.101(3.37) *$ & $-0.016(-0.37)$ & $0.026(0.96)$ & $-0.080(-1.47)$ \\
\hline \multicolumn{5}{|l|}{ Locality } \\
\hline Urban area & $0.675(10.50) *$ & $0.694(9.78) *$ & $0.538(8.91) *$ & $0.727(7.45) *$ \\
\hline Rural & $0.844(9.94) *$ & $0.752(6.81) *$ & $0.670(8.47) *$ & $1.044(7.10) *$ \\
\hline \multicolumn{5}{|l|}{ Number of children } \\
\hline $0-5$ years & $0.007(0.44)$ & $-0.032(-1.45)$ & $0.031(2.04) * *$ & $-0.016(-0.63)$ \\
\hline $6-14$ years & $-0.009(-0.68)$ & $-0.008(-0.52)$ & $0.004(0.38)$ & $-0.029(-1.46)$ \\
\hline $15-17$ years & $0.001(0.03)$ & $0.028(0.87)$ & $-0.003(-0.13)$ & $0.050(1.24)$ \\
\hline \multicolumn{5}{|l|}{ Short terms health conditions } \\
\hline Ill 14 days & $-1.058(-25.95) *$ & $-0.889(-17.81) *$ & $-1.001(-27.72) *$ & $-0.936(-14.36) *$ \\
\hline Malaria & $-0.824(-11.72) *$ & $-0.951(-10.70) *$ & $-0.822(-14.51) *$ & $-0.799(-7.56) *$ \\
\hline Diarrhea & $-0.274(-2.05) * *$ & $-0.570(-2.99) *$ & $-0.627(-4.31) *$ & $-0.922(-2.87) *$ \\
\hline \multirow{2}{*}{\multicolumn{5}{|c|}{ Long terms health condition }} \\
\hline & & & & \\
\hline Seeing & $-0.433(-3.31) *$ & $-0.107(-0.71)$ & $-0.401(-3.61) *$ & $-0.100(-0.52)$ \\
\hline Speech & $-0.472(-1.83) * * *$ & $-0.050(-0.14)$ & $0.584(1.22)$ & $4.150(0.04)$ \\
\hline Hearing & $-0.530(-2.66) *$ & $0.939(-2.41) * *$ & $-0.002(-0.01)$ & $-0.106(-0.17)$ \\
\hline Mobility & $-0.443(-3.63) *$ & $-0.420(-2.49) * *$ & $-0.468(-3.45) *$ & $-0.288(-1.09)$ \\
\hline \multicolumn{5}{|l|}{ Job characteristics } \\
\hline Hours per week & $0.003(2.88) *$ & $0.002(1.67) * * *$ & $0.002(1.67) * * *$ & $0.001(0.42)$ \\
\hline Experience & $0.0002(0.11)$ & $0.008(2.50) * *$ & $0.0004(0.23)$ & $0.003(0.64)$ \\
\hline Informal & $0.078(0.61)$ & $0.143(2.46) * *$ & $-0.464(-2.23) * *$ & $-0.063(-0.68)$ \\
\hline \multicolumn{5}{|l|}{ Activity characteristics } \\
\hline Seasonal & $0.052(1.19)$ & $0.113(1.33)$ & $0.171(4.35) *$ & $0.161(1.72) * * *$ \\
\hline Temporary & $0.035(0.49)$ & $0.032(0.59)$ & $0.016(0.26)$ & $0.050(0.70)$ \\
\hline \multicolumn{5}{|l|}{ Sector of activity } \\
\hline Industry & $0.048(0.75)$ & $0.133(1.64)$ & $0.076(1.37)$ & $0.033(0.27)$ \\
\hline Trade & $-0.007(-0.12)$ & $0.017(0.17)$ & $0.014(0.27)$ & $0.112(0.82)$ \\
\hline Services & $-0.016(-0.26)$ & $0.120(1.54)$ & $-0.019(-0.32)$ & $0.196(1.86) * * *$ \\
\hline \multicolumn{5}{|l|}{ Firm size } \\
\hline $2-5$ employees & $-0.043(-1.01)$ & $0.048(0.41)$ & $0.014(0.40)$ & $-0.051(-0.40)$ \\
\hline 6 - 20 employees & $-0.103(-1.50)$ & $0.032(0.26)$ & $0.012(0.17)$ & $-0.140(-1.02)$ \\
\hline At least 21 employees & $-0.132(-0.56)$ & $0.017(0.13)$ & $-0.202(-0.57)$ & $-0.102(-0.66)$ \\
\hline Cut 1 & $-1.772(4.74) *$ & $-0.862(-1.74) * * *$ & $-2.388(-6.35) *$ & $0.613(0.97)$ \\
\hline Cut 2 & $-0.484(-1.30)$ & $0.570(1.16)$ & $-1.076(-2.87) *$ & $2.003(3.19) *$ \\
\hline Cut 3 & $0.440(1.18)$ & $1.420(2.49) * *$ & $-0.108(-0.288)$ & $2.976(4.73) *$ \\
\hline Observations & 5422 & 3826 & 5821 & 2007 \\
\hline Log likelihood & -4563.303 & -3263.859 & -5611.814 & -1887.348 \\
\hline Pseudo R2 & 0.164 & 0.135 & 0.168 & 0.135 \\
\hline $\begin{array}{l}\text { Joint significant of instruments } \\
\text { variables }\end{array}$ & $\operatorname{chi} 2(8)=1325.80 *$ & $\operatorname{chi} 2(8)=748.88 *$ & $\operatorname{chi} 2(8)=1634.76 *$ & $\begin{array}{c}\operatorname{chi2}(8)=415.86 \\
*\end{array}$ \\
\hline Test of validity of instruments & LR chi2 $(8)=1389.62 *$ & LR chi2 (8)=781.70 * & $\begin{array}{c}\text { LR chi2 }(8)=1727.35 \\
*\end{array}$ & $\begin{array}{c}\text { LR chi2 } \\
(8)=434.72 *\end{array}$ \\
\hline
\end{tabular}

Note: 1. t-statistics in parentheses.

2. * ** and $* * *$ represent statistical significance at the $1 \%, 5 \%$ and $10 \%$ respectively. 
Table A3: Reduced form estimates for labour income

\begin{tabular}{|c|c|c|c|c|}
\hline & \multicolumn{2}{|c|}{ Men } & \multicolumn{2}{|c|}{ Women } \\
\hline & Self -employed & "Wage earner & Self -employed & Wage earner \\
\hline Age & "0.0227 (2.46) ** & $0.023(1.98) * *$ & $0.008(0.99)$ & $-0.003(-0.18)$ \\
\hline Age squared & $-0.0003(-2.79) *$ & $-0.0002(-1.52)$ & $-0.0001(-1.06)$ & $-0.00002(-0.09)$ \\
\hline Single & $-0.027(-0.58)$ & $-0.102(-2.13) * *$ & $0.081(1.86) * * *$ & $-0.036(-0.57)$ \\
\hline Head & $0.071(1.42)$ & $0.126(2.64) *$ & $0.025(0.79)$ & $0.099(1.47)$ \\
\hline \multicolumn{5}{|l|}{ Education } \\
\hline Primary & $0.109(2.87) *$ & $0.081(1.23)$ & $0.048(1.42)$ & $0.168(1.95) * * *$ \\
\hline Secondary 1st & $0.200(4.35) *$ & $0.146(2.12) * *$ & $0.044(0.99)$ & $0.248(2.52) * *$ \\
\hline Secondary $2^{\text {nd }} \&+$ & $0.390(7.30) *$ & $0.491(6.95) *$ & $0.209(3.28) *$ & $0.578(5.12) *$ \\
\hline " Vocational training & $0.073(2.37) * *$ & $0.211(5.96) *$ & $0.077(2.48) * *$ & $0.203(3.58) *$ \\
\hline NL income & $0.0003(3.65) *$ & $0.0002(2.25) * *$ & $0.0003(2.03) * *$ & $0.0004(2.08) * *$ \\
\hline NL income 2 & $-6.25 \mathrm{e}-09(-2.26) * *$ & $-1.48 \mathrm{e}-08(-0.95)$ & $-8.27 \mathrm{e}-08(-1.86) * * *$ & $\begin{array}{c}-1.38 \mathrm{e}-08(-2.04) \\
* *\end{array}$ \\
\hline \multicolumn{5}{|l|}{ Job history 2001} \\
\hline Self employed & $0.133(2.12) * *$ & $0.110(1.70) * * *$ & $0.088(1.30)$ & $0.131(1.32)$ \\
\hline Salaried & $0.151(1.94) * * *$ & $0.206(3.77) *$ & $0.114(0.99)$ & $0.341(3.89) *$ \\
\hline Training/ search & $0.046(0.75)$ & $0.024(0.50)$ & $-0.031(-0.47)$ & $-0.034(-0.46)$ \\
\hline \multicolumn{5}{|l|}{ Regional variables } \\
\hline Log employed & $-0.352(-8.17) *$ & $-0.392(-7.45) *$ & $-0.372(-9.20) *$ & $-0.241(-2.88) *$ \\
\hline Log unemployment & $0.260(10.56) *$ & $0.228(7.09) *$ & $0.262(11.00) *$ & $0.101(2.13) * *$ \\
\hline \multicolumn{5}{|l|}{ Locality } \\
\hline Urban area & $-0.311(-5.88) *$ & $-0.253(-4.94) *$ & $-0.167(-3.23) *$ & $-0.535(-6.40) *$ \\
\hline Rural & $-0.328(-4.78) *$ & $-0.436(-5.49) *$ & $-0.249(-3.71) *$ & $-0.783(-6.31) *$ \\
\hline \multicolumn{5}{|l|}{ Number of children } \\
\hline $0-5$ years & $0.007(0.55)$ & $-0.046(-2.86) *$ & $0.0007(0.06)$ & $-0.052(-2.36) * *$ \\
\hline $6-14$ years & $-0.006(-0.52)$ & $0.002(0.13)$ & $0.008(0.77)$ & $-0.024(-1.39)$ \\
\hline $15-17$ years & $0.024(1.04)$ & $0.039(1.64)$ & $-0.010(-0.48)$ & $0.045(1.28)$ \\
\hline \multicolumn{5}{|c|}{ Short terms health conditions } \\
\hline Ill 14 days & $-0.035(-1.00)$ & $-0.034(-0.88)$ & $0.024(0.78)$ & $0.036(0.61)$ \\
\hline Malaria & $0.101(1.58)$ & $-0.107(-1.46)$ & $-0.0003(-0.01)$ & $0.027(0.27)$ \\
\hline Diarrhea & $-0.079(-0.64)$ & $0.002(0.01)$ & $0.066(0.50)$ & $-0.688(-2.27) * *$ \\
\hline Resp. Infection & $-0.101(-1.39)$ & $0.0003(0.00)$ & $-0.077(-1.31)$ & $-0.058(-0.52)$ \\
\hline \multicolumn{5}{|c|}{ Long terms health condition } \\
\hline Seeing & $-0.092(-0.85)$ & $-0.074(-0.62)$ & $-0.146(-1.44)$ & $0.056(0.31)$ \\
\hline Speech & $-0.113(-0.50)$ & $0.127(0.50)$ & $0.085(0.22)$ & $-0.661(-0.90)$ \\
\hline Hearing & $0.111(0.63)$ & $0.224(0.69)$ & $0.325(1.51)$ & $-0.079(-0.15)$ \\
\hline Mobility & $-0.019(-0.18)$ & $0.027(0.20)$ & $0.028(0.24)$ & $-0.270(-1.16)$ \\
\hline \multicolumn{5}{|l|}{ Job characteristics } \\
\hline Hours per week & $0.003(3.81) *$ & $0.0003(0.39)$ & $0.004(4.68) *$ & $0.002(1.58)$ \\
\hline Experience & $0.003(1.75) * * *$ & $0.006(2.36) * *$ & $-0.00005(-0.03)$ & $0.012(2.98) *$ \\
\hline Informal & $-0.699(-6.42) *$ & $-0.242(-5.70) *$ & $-0.690(-4.16) *$ & $-0.408(-5.09) *$ \\
\hline \multicolumn{5}{|l|}{ Activity characteristics } \\
\hline Seasonal & $-0.064(-1.78) * * *$ & $-0.068(-1.11)$ & $-0.046(-1.40)$ & $-0.335(-4.21) *$ \\
\hline Temporary & $-0.062(-1.06)$ & $-0.120(-3.03) *$ & $0.075(1.41)$ & $-0.019(-0.30)$ \\
\hline \multicolumn{5}{|l|}{ Sector of activity } \\
\hline Industry & $0.001(0.01)$ & $0.070(1.16)$ & $-0.205(-4.36) *$ & $-0.350(-3.25) *$ \\
\hline Trade & $0.053(1.02)$ & $-0.032(-0.42)$ & $-0.178(-3.90) *$ & $-0.372(-3.05) *$ \\
\hline Services & $-0.001(-0.03)$ & $0.078(1.36)$ & $-0.180(-3.58) *$ & $-0.242(-2.60) *$ \\
\hline \multicolumn{5}{|l|}{ Firm size } \\
\hline $2-5$ employees & $0.088(2.57) *$ & $0.029(0.34)$ & $0.071(2.31) * *$ & $0.176(1.58)$ \\
\hline 6 - 20 employees & $0.186(3.28) *$ & $0.101(1.15)$ & $0.137(2.22) * *$ & $0.282(2.37) * *$ \\
\hline At least 21 employees & $0.494(2.43) * *$ & $0.195(2.09) * *$ & $0.402(1.39)$ & $0.291(2.18) * *$ \\
\hline Constant & $11.698(38.64) *$ & $11.509(31.87) *$ & $12.018(38.41) *$ & $11.680(21.58) *$ \\
\hline Observations & 5422 & 3826 & 5821 & 2007 \\
\hline Adjusted R2 & 0.1003 & 0.2913 & 0.0486 & 0.3131 \\
\hline
\end{tabular}

Note: 1. t-statistics in parentheses.

2. *, $* *$ and $* * *$ represent statistical significance at the $1 \%, 5 \%$ and $10 \%$ respectively. 


\section{Acknowledgements}

We acknowledge financial assistance from the African Economics Research Consortium. The authors acknowledge the substantial comments and suggestions received from AERC resources persons of collaborative project on "Health, Economics Growth and Poversty Reduction in Africa”, Germain Ndjieundé, Tsafack Nanfosso, Kamala Kaghoma and participants to various seminars and conferences.

\section{References}

Averett, S. and S. Korenman (1996) 'The economic reality of the beauty myth', Journal of Human Resources, 31: $301-330$.

Baldwin, M. and W. Johson (1994) 'Labor Market Discrimination against Men with Disabilities', Journal of Human Resources, 29: 1-19.

Behrman, J.R. and M.R. Rosenzweig (2004) 'Returns to Birth weight', The Review of Economics and Statistics, 86: 586 - 601 .

Bhattacharya, J. and M.K. Bundorf (2005) 'The incidence of the health care costs of obesity', National Bureau of Economic Research Working Paper. 01 - 52.

Bound, J. (1991) 'Self-reported health versus objective measures of health in retirement models', Journal of Human Resources, 58: 106 - 138.

Bound, J., M. Schoenbaum and T. Waidman (1995) 'Race and education differences in disability status and labor force attachment in the health and retirement survey'. Journal of Human Resources. 30: S227 - S267.

Bound, J., M. Schoenbaum and T. Waidman (1999) 'The dynamic effects of health on the labour force transitions of older workers', Labour Economics, 10: 227 - 252.

Breslow, L. (1989) 'Health Status Measurement in the Evaluation of Health Promotion', Medical Care, 27: S205-S216.

Cai, L. (2007) 'Effects of health on wages of Australian men', Working Paper Series 2007/02. Melbourne: University of Melbourne, Institute of Applied Economic and Social Research.

Cai, L. (2010) 'The relationship between health and labour force participation: Evidence from a panel data simultaneous equation model', Labour Economics, 17: 77 - 90.

Cawley, J. (2004) 'The impact of obesity on wages’ Journal of Human Resources, 39: 451 - 474.

Chriskos, T.N. (1993) 'The Relationship between Health and Labor Market Status', Annual Reviews of Public Health, 14 : 293-312.

Dumont, J.C. 2000. Santé, Education et Développement: une Approche Systémique de l'Hétérogénéité du Capital Humain. Analyse Théorique et Applications au cas de Madagascar. Thèse de Doctorat, non Publiée, Université Paris IX Dauphine. 
Dwyer, D.S. and O.S. Mitchell (1999) 'Health Problems as Determinants of Retirement: are Self-rated Measures Endogeneous?', Journal of Health Economics, 18: 173-193.

Gallup, J.L. and F. Sachs (2001) 'The Economic Burden of Malaria’, Am. J. Trop. Med. Hyg., 64: 8596.

Grossman, M. (1972) 'On the Concept of Health Capital and the Demand for Health', Journal of Political Economy, 80: 223-255.

Grossman, M. (1999) 'The human capital model of the demand for health', In: Newhouse, J.P., Culyer, A.J. (Eds.), Hanbook of Health Economics. North-Holland, Amsterdam.

Gertler, P. and J. Gruber (2002) 'Insuring Consumption against Illness’, American Economic Review, 92: $51-70$.

Han, E., C. Edward, Norton and S.C. Stearns (2009) 'Weight and wages: Fat versus lean paychecks', Health Economics, 18: 535 - 548.

Jäckle, R. and O. Himmler (2010) 'Health and wages: Panel data estimates considering selection and endogeneity', Journal of Human Resources, 45: 364 - 406.

Kamgnia Dia, B. (2007) 'The Demand for Malaria Control Products and Services: Evidence from Yaoundé, Cameroon' In Fosu A. and Mwabu G. (eds), Malaria and Poverty in Africa, AERC Collaborative Research on Malaria and Poverty in Africa, University of Nairobi Press, Chapter 5, 105155.

Kenkel, D.S. (1995) 'Should you eat breakfast? Estimates from health production functions', Health Economics, 4: 15 - 29.

Kreider, B. (1999) 'Latent work disability and reporting bias', Journal of Human Resources, 34: 734 769.

Leung S.F. and C.T. Wong (2002) 'Health Status and Labor Supply: Interrelationship and Determinants',. Hong Kong University of Science and Technology, mimeo.

Lundberg, O. and K. Manderbacka (1996) 'Assessing reliability of a measure of self-rated health', Scandinavian Journal of Social Medecine, 24: 218 - 224.

Maddala, G.S. (1983) Limited Dependent and Qualitative Variables in Econometrics. Cambridge, Cambridge University Press.

Maloney, W.F. (2004) 'Informality Revisited’, World Development, 32: 1159 - 1178.

Mwabu, G. (2007) 'The Economic Burden of Malaria in Kenya', In Fosu A. and Mwabu G. (eds), Malaria and Poverty in Africa, AERC Collaborative Research on Malaria and Poverty in Africa, University of Nairobi Press, Chapter 3, 45-72.

Mwabu, G. and A. Fosu (2007) 'Understanding Malaria and Poverty in Africa: A Framework', In Fosu A. and Mwabu G. (eds), Malaria and Poverty in Africa, AERC Collaborative Research on Malaria and Poverty in Africa, University of Nairobi Press, Chapter 2, 11-41. 
Perronnin, M., L. Rochaix and S. Tubeuf (2006) 'Construction d'un Indicateur Continu d'Etat de Santé Agrégeant Risque Vital et Incapacité, Questions d’Economie de la Santé', Bulletin d'Informations en Économie de la Santé, IRDES, 107.

Schultz, T.P. (2002) 'Wage gains associated with height as a form of health human capital', American Economic Review, 92: 349 - 353.

Schultz, T.P. and A. Tansel (1997) 'Wage and labor supply effects of illness in Cote d'Ivoire and Ghana: Instrumental variable estimates for days disabled', Journal of Development Economics, 53: $251-286$.

Stern, S. (1989) 'Measuring the Effect of Disability on Labour Force Participation', The Journal of Human Resources, 24: 361-395.

Tausman, P. and S. Rosen (1982) 'Healthiness, education and marital status' In V. Fuchs, (Eds.), Economics Aspects of Health: University of Chicago Press.

Thomas, D. and J. Strauss (1997) 'Health and Wages: Evidence on Men and Women in Brazil', Journal of Econometrics, 77: 159-185.

Waldron I. (1991) 'Patterns and Causes of Gender Differences in Smoking', Social Science and Medecine, 32: 989-1005.

Weil, D.N. (2008) 'Endemic Diseases and African Economic Growth: Challenge and Policy Responses', Journal of African Economies, 19: iii81 - iii109. 